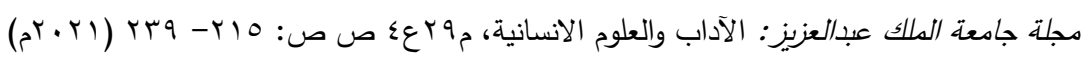

DOI:10.4197/Art.29-4.9

\title{
ظاهرة ضعف ملكة التقسير في العصر الحديث ووسائل علاجها
}

\author{
د. صالح بن أحمد بن عبيد العلوي

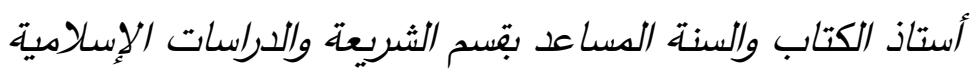 \\ كلية الآداب والعلوم الإنسانية - جامعة الملك عبد العزيز
}

مستخلص. تناول هذا البحث ظاهرة ضعف ملكة التقسير في العصر الحديث وأسبابها ووسائل علاجها.

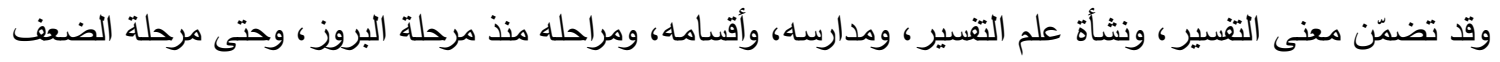
والكمون.

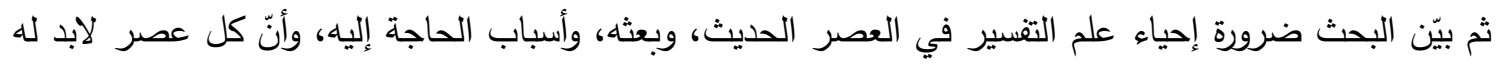

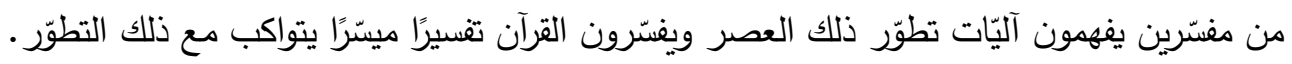

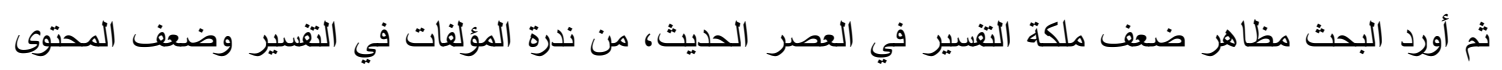
العلمي للمصنفات فيه، والاعتماد الواضح في النقل الحرفي لبعض من كتبوا في التتسير في العصر الحيثر العيث.

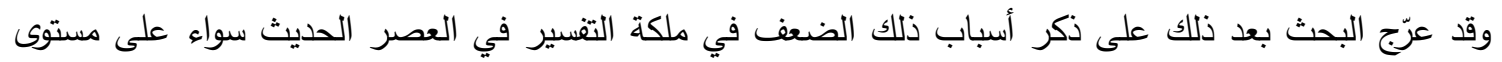

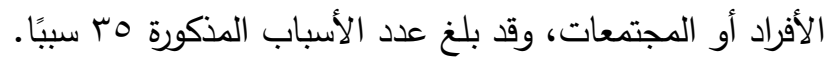

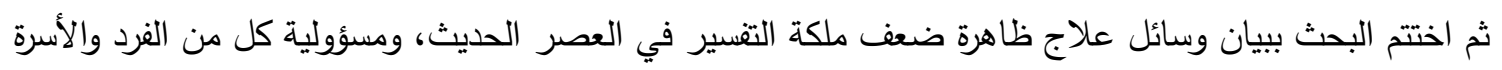

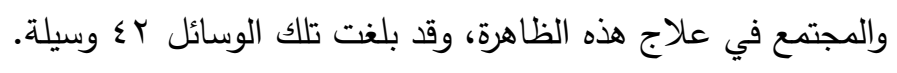

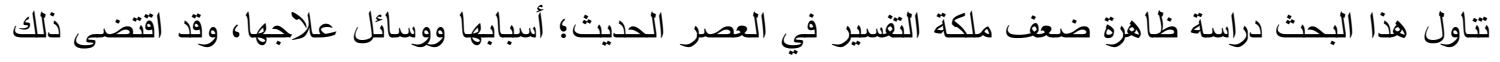

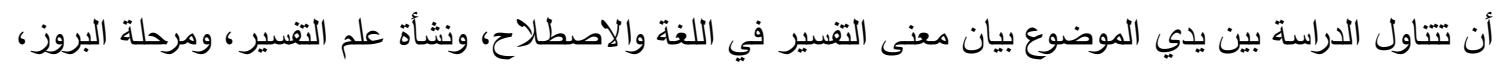

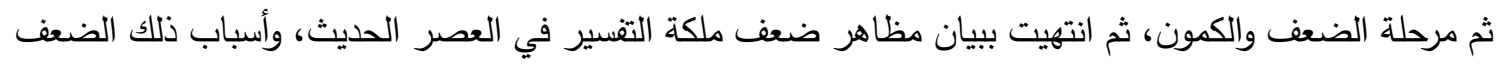
ووسائل علاجها.

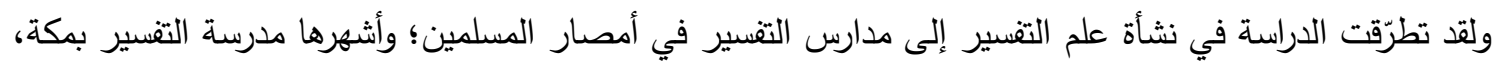
ومدرسة التنسير بالمدينة، ومدرسة التقسير بالعراق. كما تناولت الدراسة في مرحلة البروز أقسام المصنّفات في التفسير، وشملت: التفسير المأثور، والتفسير بالرأي. 


$$
\text { صالح بن أحمد بن عبيد العلوي }
$$

ثم أظهرت الدراسة أسباب انصراف الدعاصرين عن الخوض في تفسير القرآن؛ ومنها توسّع متقدمي الدفسرين في

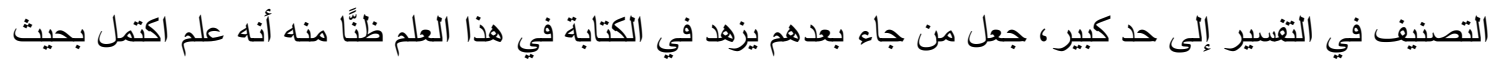

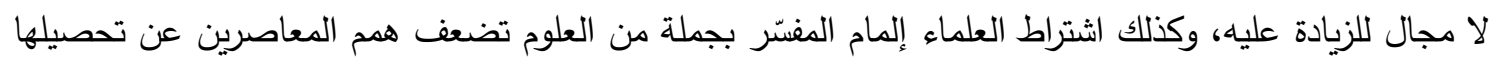
مجتمعة، ممّا أدىى إلى ضعف ملكة التئسير عندهم وغياب الموهبة.

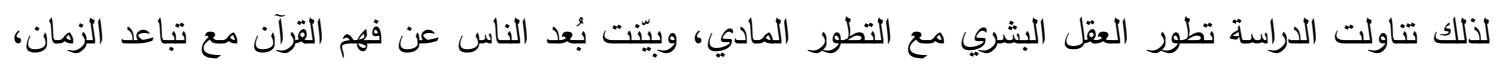

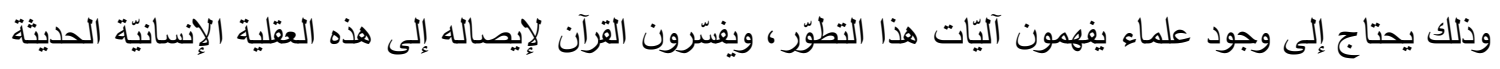

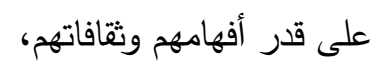

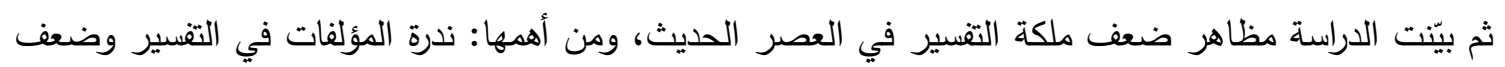

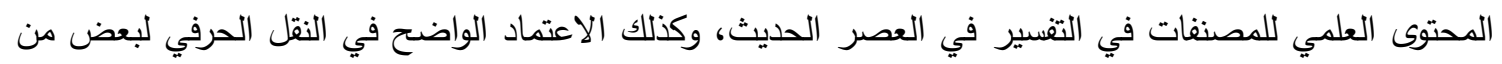

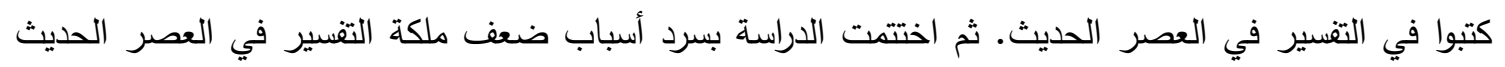
وبيان وسائل علاج ذلك.

لذلك كانت خطة هذا البحث كالتالي: المقدمة: وفيها غاية هذا البحث، وخطّته. التمهيد: وفيه معنى التقسير في اللغة والاصطلاح. المبحث الأول: نشأة علم التفسير .

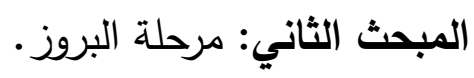
المبحث الثالث: مرحلة الضعف والكمون. المبحث الرابع: ضرورة إحياء العلم وبعثه وأسباب

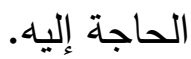
المبحث الخامس: مظاهر ضعف ملكة التنسير في العصر الحديث. المبحث السادس: أسباب ضعف ملكة التقسير في العصر الحديث. المبحث السابع: وسائل علاج ضعف ملكة التقسير في العصر الحديث.

\section{المقدمة}

الحمد لله وحده، والصلاة والسلام على نبيه محمد وعلى آله وصحبه أجمعين.

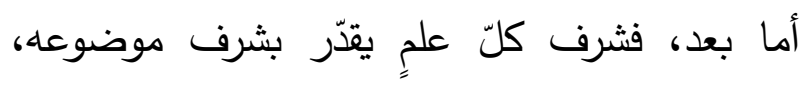

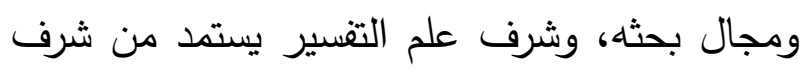
مجال بحثه، فليس هناك ما هو أعظم من القرآن الكريخ. وغاية هذا البحث هو مناقثة أسباب ندرة المفسرين في العصر الحديث، ومعالجة تلك المشكلة بوضع آليّة لإعادة علم التفسير إلى الساحة العلميّة. لكن قبل مناقشة ذلك، كان لابدّ أولًا من معرفة ماهيّة

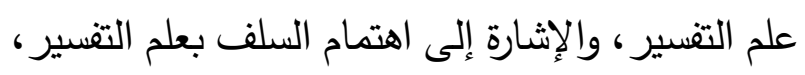

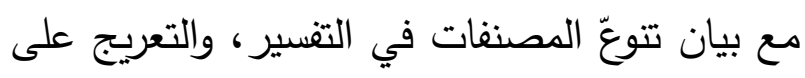

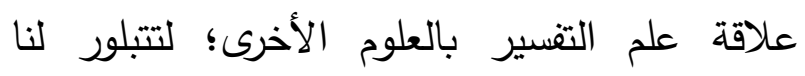

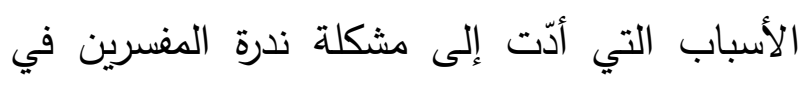
العصر الحديث ليتهيّأ لنا وضع الآليّة العلميّة 
الإفرادية والتركيبية، ومعانيها التي تحمل عليها حالة التمهيد التركيب، وتتمات لذلك"(\{).وعرفه الزركثي بأنه: "علم معنى التفسير في اللغة: يعرف به فهم كتاب الله المنزل على نبيه محمد صلى الله عليه وسلم وبيان معانيه واستخراج أحكامه وحكمه بنه واستمداد ذلك من علم اللغة والنحو والتصريف وعلم البيان وأصول الفقه والقراءات ويحتاج لمعرفة أسباب

$$
\text { النزول والناسخ والمنسوخ"(o). }
$$

وعرفه بعضهم بأنه: "علم يبحث فيه عن أحوال القرآن الكريخ، من حيث دلالته على مراد الله تعالى، بقدر

$$
\text { الطاقة البشرية"(7). }
$$

وقيل فيه: "علم نزول الآيات، وشئونها، وأقاصيصها،

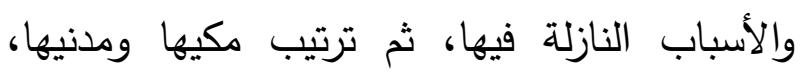
ومحكمها ومتشابهها، وناسخها ومنسوخها، وخاصها وعامها، ومطلقها ومقيدها، ومجملها ومفسرها، وحلالها

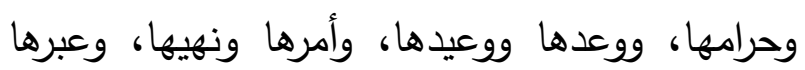

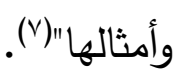

$$
\text { نثأة علم التفسير الأول }
$$

لم يكن غربيًا أن يفهم أصحاب النبي صلى الله عليه وسلم القرآن في جملته بالنسبة لظاهره وأحكامه؛ لأنه نزل بلسانهم اللسان العربي المبين، أما معرفة دقائق بانق

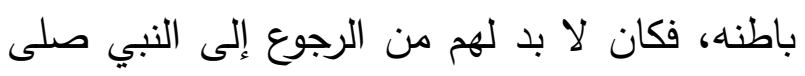

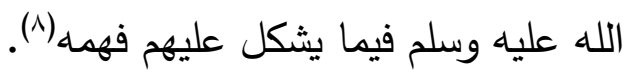

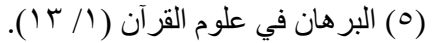

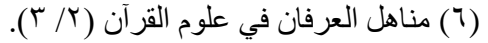

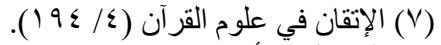

(^) المسائل والأجوبة لابن فتيبة (ص: ^^ ع ).
(1) القاموس المحيط (ص: (10) (10) ؛ ).

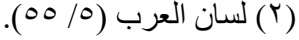

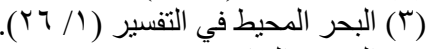

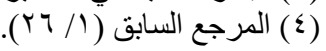

ويرى آخرون أن التفسير قابل للتعريف كغيره من

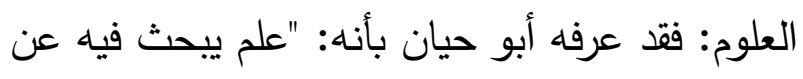
كيفية النطق بألفاظ القرآن، ومدلولاتها، وأحكامها ليانها 
وقد اشتهر من تلاميذ ابن عباس بمكة ثلاثة: عكرمة

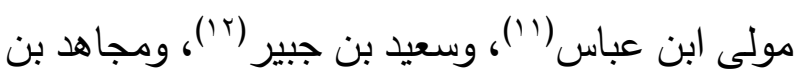

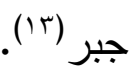

\section{ثانيا: مدرسة التفسير بالمدينة}

وقيام هذه على أبي بن كعب رضي الله عنه، فرغم كثرة الصحابة الذين أقاموا بالمدينة ولم يتحولوا عنها كما تحوّل كثير منهم إلى غيرها من بلاد المسلمين، فجلسوا لأتباعهم يعلمونهم كتاب الله تعالى وسنة

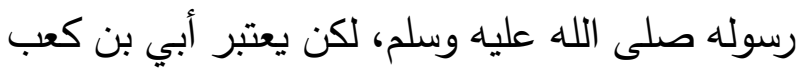
أشهر من تتلمذ له مفسرو التابعين بالمدينة، وذلك لك لشهرته أكثر من غيره في التقسير ، وكثرة ما نُقل لنا عنه في ذلك، وقد قال رسول الله صلى الله عليه وسلم: 》استقرئوا القرآن من أربعة، من عبد الله بن فئ

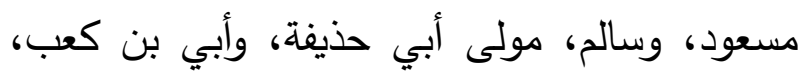

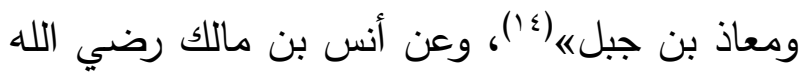
عنه قال: قال رسول الله صلى الله عليه وسلم لأبي بن كعب: "إن الله أمرني أن أقرأ عليك طلم يكن الذين

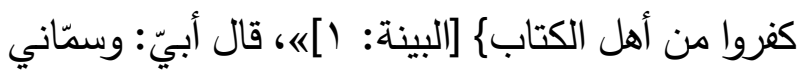

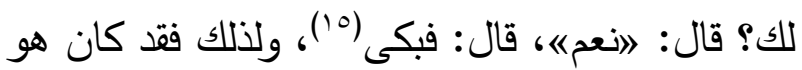
الذي يؤم بالناس في رمضان بأمر عمر بن الخطاب رضي الله عنه؛ فعن عبد الرحمن بن عبد القاري، أنه بـ باله قال: خرجت مع عمر بن الخطاب رضي الله عنه، ليلة في رمضان إلى المسجد، فإذا الناس أوزاع
ولمّا فتح الله على المسلمين كثيرا من بلاد العالم، تفرّق الصحابة رضوان الله عليهم في أرض الله بله الواسعة، وحملوا معهم ما حفظوه عن رسول الله صلى لـ الله عليه وسلم، فجلس إليه كثير من التابعين يأخذون العلم عنهم، وينقلونه لمن بعدهم. من أجل ذلك قامت في كبرى أمصار المسلمين المختلفة مدارس علمية، أساتذتها الصحابة، وتلاميذها

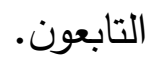
واشتهر بعض هذه المدارس بالتقسير خاصصّة، وتتلمذ فيها كثير من التابعين لمشاهير المفسرين من الصحابة، وكان أشهر مدارس التفسير في الأمصار في ذلك العصر ثلاث مدارس: مدرسة مكة، ومدرسة التها المدينة، ومدرسة العراق(9). أولا: مدرسة التفسير بمكة كان قيام هذه المدرسة على الحبر ابن عباس رضي

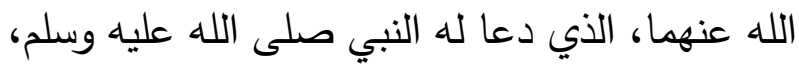
فقال في دعائه له: "اللهم فقهه في الدين، وعلّمه التأويل"(·)، فكان يجلس لأصحابه من التابعين، يفسّر

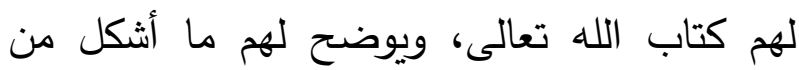

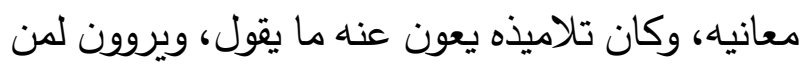

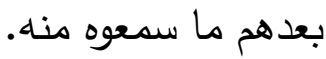


وقد وجد بالمدينة في هذا الوقت كثير من التابعين المعروفين بالتفسير، اشتهر من بينهح ثلاثة: أبو

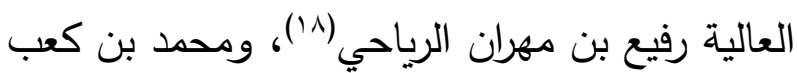
القرظي(9) (19)، وزيد بن بن أسلم (r.r) ثالثا: مدرسة التفسير بالعرلق

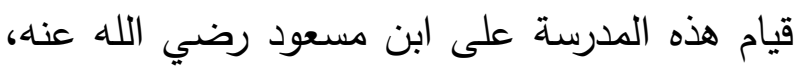

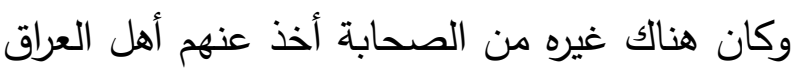
التقسير، غير أن عبد الله بن مسعود كان يعتبر الهابه الأستاذ الأول لهذه المدرسة، نظرًا لشهرته في التفسير

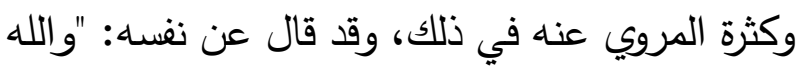
الذي لا إله غيره، ما نزلت آية من كتاب اللَّه إلا وأنا أعلم فيمن نزلت وأين نزلت؟ ولو أعلم مكان أحد أعلم بكتاب اللَّه مني تناله المطايا لأتيته"('(r). وقد عرف بالتتسير من أهل العراق من أصحاب ابن لان لان لان مسعود كثير من التابعين، اشتهر من بينهم ثلاثة:

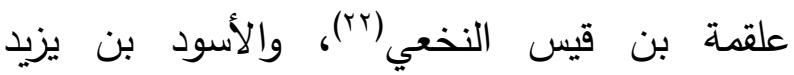

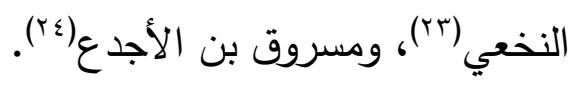

فهؤلاء هم مشاهير المفسرين من التابعين، وغالب أقوالهم في التفسير تلقوها عن الصحابة، ولا شك أنهح كانوا على مبلغ عظيم من العلم ودقة الفهم، لقرب

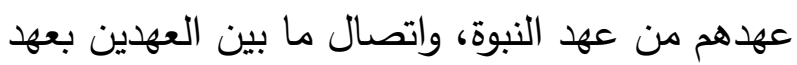

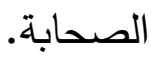

متفرقون، يصلي الرجل لنفسه، ويصلي الرجل فيصلي بصلاته الرهط، فقال عمر : اإني أرى لو جمعت هؤلاء على قارئ واحد، لكان أمثله ثم عزم، فجمعهم على لـ إنى أبي بن كعب(17) وقد كان الصحابة رضوان الله عليهم أنفسهم يسألونه عن التفسير؛ فعن ابن عباس رضي الله عنهما أنه تمارى هو والحر بن قيس بن حصن الفزاري في صاحب موسى، فمر بهما أبي بن كعب، فدعاه ابن بن هُ هن

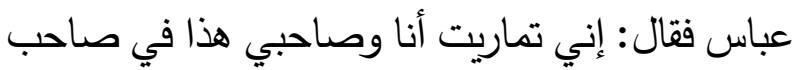
موسى الذي سأل السبيل إلى لقيه، هل سمعت رسول

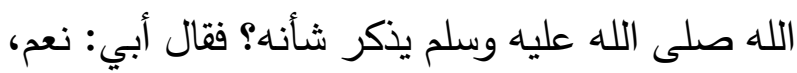
سمعت النبي صلى الله عليه وسلم يذكر شأنه يقول: " بينما موسى في ملإ من بني إسرائيل، إذ جاءه رجل فقال: أتعلم أحدا أعلم منك؟ قال موسى: لا، فأوحى منى الله عز وجل إلى موسى: بلى، عبدنا خضر، فسأل السبيل إلى لقيه، فجعل الله له الحوت آية، وقيل له: إذا فقدت الحوت فارجع، فإنك ستلقاه، فكان موسى لهی صلى الله عليه يتبع أثر الحوت في البحر، فقال فتى لهى موسى لموسى: \}أرأيت إذ أوينا إلى الصخرة فئ فإني

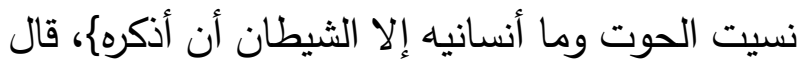
موسى: كذلك ما كنا نبغي فارتدا على آثارهما

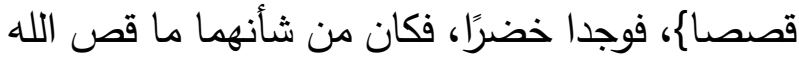

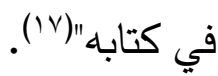

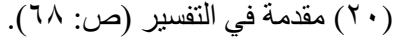

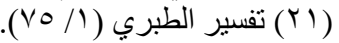

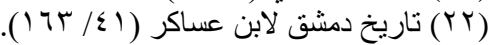

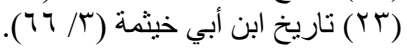

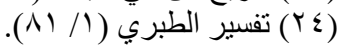

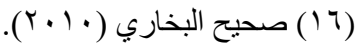

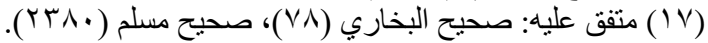

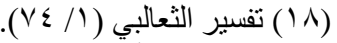

(19) التفسير المأمون على منهج التنزيل والصحيح المسنون (1) (1) (1)
} 
أنه باب من أبواب الحديث المختلفة، يجمعون فيه ما

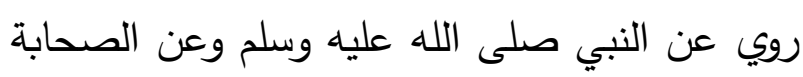
والتابعين.

ثم بعد ذلك انفصل التفسير عن الحديث، وأفرد بتأليف

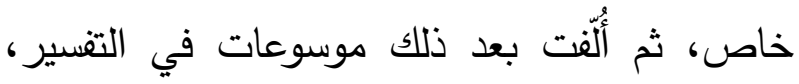

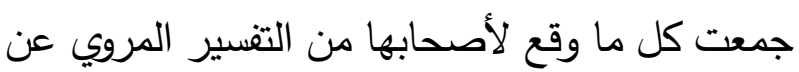
النبي صلى الله عليه وسلم وأصحابه وتابعيهج؛ كتفسير ابن جرير الطبري وتفسير ابن أبي حاتم وتفسير البغوي ونحوهم. ويلاحظ أن ابن جرير ومن على شاكلته وإن نقلوا

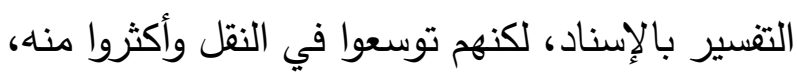
حتى استفاض وشمل ما ليس موثوقا به؛ حتى لقد نقل

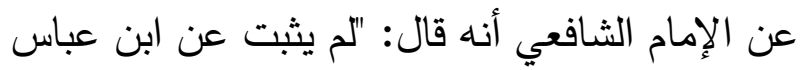

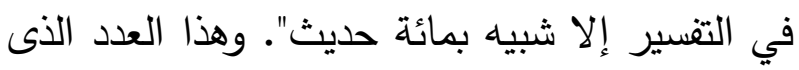

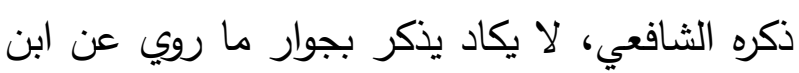

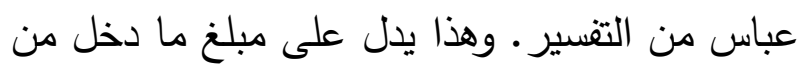
التفسير النقلي من الروايات المكذوبة المصنوعة.

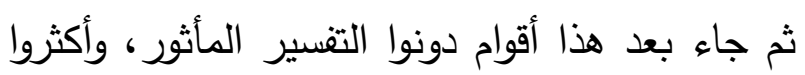
من نقل الأقوال في تفاسيرهم بدون تفرقة بين الصحيح

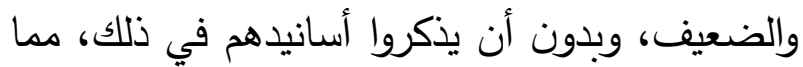
يجعل الناظر في هذه الكتب لا يركن لما جاء فيها،

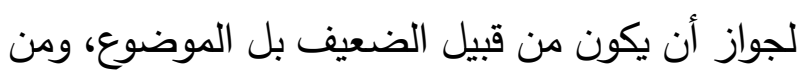

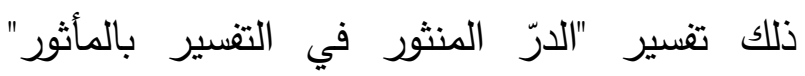
للسيوطي.
ثم حمل أتباع التابعين هذا التراث العلمي الذى خلفه التابعون، وزادوا عليه بمقدار ما زاد من الغموض وما جد من اختلاف في الرأي، وعن هؤلاء أخذ من جاء

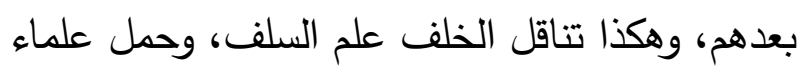
كل جيل علم من سبقهم وزادوا عليه. المبحث الثاني مرحلة البروز

ليس من السهل أن نعيّن من سبق إلى وضع مصنّف مستقل في تقسير القرآن على وجه التحقيق؛ لأنه لم يقع لنا كل ما كتب من التفسير من مبدأ عهد التدوين.

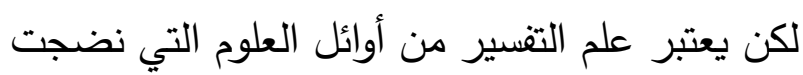

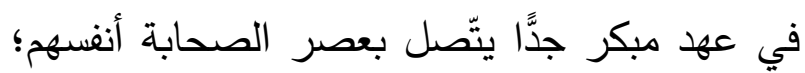
فكان أول ما عرف لنا من ذلك، تلك الصحيفة التي لتصني رواها علي بن أبى طلحة عن ابن عباس(ro). ويمكن تقسيم المصنّفات في التفسير بحسب الطريقة المتّبّعة في التقسير إلى ما يلي: أولا: التفسير المأثور: ويشمل التفسير المأثور ما جاء في القرآن نفسه من المن

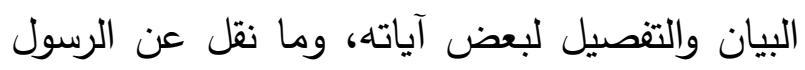

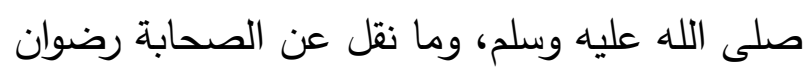
الله عليهم، وما نقل عن التابعين، من كل ما هو بيان وتوضيح لمراد الله تعالى من نصوص كتابه الكريم. والتفسير المأثور هو أوّل ما دوّن من التفسير، فكان نهان

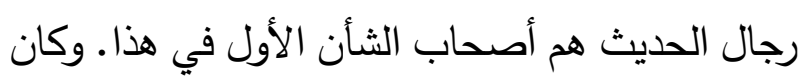
التفسير عندهم لا يفرد بالتدوين، بل كان يكتب على اهلى لابن 
للتفسير بالرأي، وقد قال شيخ الإسلام ابن تيمية بعد أن ساق الآثار عمّن تحرّج من السلف من القول في التفسير : "فهذه الآثار الصحيحة وما شاكلها عن أئمة السلف، محمولة على تحرجهم عن الكلام في التفسير بما لا علم لهم به، فأما من تكلم بما يعلم من ذلك لغة وشرعا فلا حرج عليه، ولهذا روى عن هؤلاء وغيرهم أقوال في التقسير ، ولا منافاة، لأنهم تكلموا فيما علموه، وسكتوا عما جهلوه، هذا هو الواجب على كل أحد، فإنه كما يجب السكوت عما لا عمل لله به، فكذلك يجب القول فيما سئل عنه مما يعلمه، لقوله تعالى:

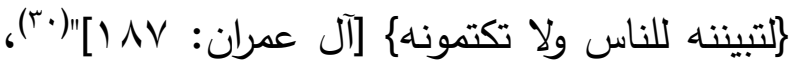
ومن كتب التفسير بالرأي على هذا المعنى: مفاتيح الغيب للرازي(آم)، وأنوار التتزيل وأسرار التأويل للبيضاوي(rr)، وروح المعاني في تفسير القرآن العظيم والسبع المثاني للألوسي.

\section{المبحث الثالث}

\section{مرحلة الضعف والكمون}

لا شكّ أن متقدمي المفسرين قد توسعوا في التقسير إلى حد كبير، جعل من جاء بعدهم يزهد في الكتابة في هذا العلم ظنَّا منه أنه علم اكتمل بحيث لا مجال للزيادة عليه، ممّا أدّى إلى ضعف ملكة التفسير

$$
\text { عندهم. }
$$

لكن حقيقة الأمر أن انصراف المعاصرين عن الخوض في تفسير الترآن يرجع إلى أمور أخرى، من أهمها
ومن أشهر ما دون من كتب التقسير المأثور : جامع البيان في تفسير القرآن، لابن جرير الطبري(؟r(ب).

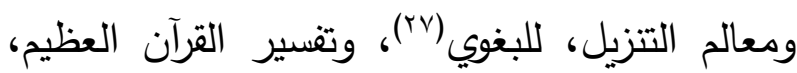
لابن كثير (rᄉ). ثانيا: التفسير بالرأي: - (التي المراد بالرأي هنا "الاجتهاد" وعليه فالتفسير بالرأي عبارة عن تفسير القرآن بالاجتهاد بعد معرفة المفسّر لكلام العرب ومناحيهم في القول، ومعرفته للألفاظ العربية ووجوه دلالاتها، واستعانته في ذلك بالشعر الجاهلي ووقوفه على أسباب النزول، ومعرفته بالناسخ والمنسوخ من آيات القرآن، وغير ذلك من الأدوات التي يحتاج إليها المفسر، وهذا النوع من التفسير جائز لا شك فيه. وأما إذا كان التفسير بالرأي غير جار على قوانين العربية، ولا موافق للأدلة الشرعية، ولا مستوف لشرائط التفسير، فهذا هو التفسير المذموم الذي حذّر منه السلف، وعليه يحمل كلمهح في التحذير منه؛ كقول عمر بن الخطاب رضي الله عنه: الما أخاف على هذه الأمة من مؤمن ينهاه إيمانه ولا من فاسق بين فسقه، ولكني أخاف عليها رجلا قد قرأ القرآن حتى أزلفه بلسانه ثم تأوله على غير تأويلهـ(ج9). فهذا ونحوه، وارد في حقّ من لا يراعي في تفسير القرآن قوانين اللغة ولا أدلة الثريعة، ويجعل هواه ومذهبه قائده، وهذا هو الذى يحمل عليه كلام المانعين
(Y) (Y) مقدمة في أصول التفسير (ص: Y + ( )).

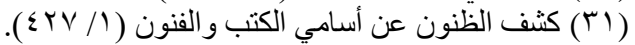

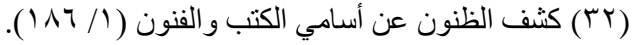

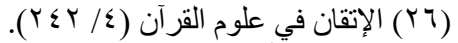

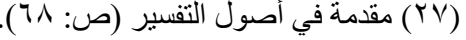

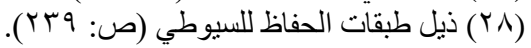

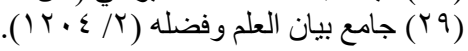


معروف، وكان له أصحاب ينتحلون مذهبه يقال لهم "الجريرية"(rr"، وقال السيوطي عن الطبري: "وكان أولًا شافعيًّا ثم انغرد بمذهب مستقل، وأقاويل واختيارات، وله أتباع مقلدون، وله في الأصول والفروع كتب كثيرة"(๕ז)، ولكن هذا المذهب الذى أسسه لم يُكتب

البقاء كالمذاهب الأربعة المعروفة. وهذه العلوم التي ذكرها العلماء والتي يلزم المفسّر العلم بها لا تكاد تجتمع لشخص واحد في العصر الحديث، ويمكن تلخيصها فيما يلي: الأول: علم الحديث والأثر؛ لتفسير المجمل والمبهم؛ ليستعين بها على توضيح ما يشكل عليه، ويشمل ذلك العلم بأحوال الرجال والتراجم ومصطلح الحديث وعلله؛ لتمييز صحيح أسانيد تلك الأحاديث والآثار من سقيمها.

الثاني: علم اللغة والغزبب؛ لأن به يمكن شرح دفردات الألفاظ ومدلولاتها بحسب الوضع، لابد من التوسع والتبحر في ذلك، لأن اليسير لا يكفى، إذ ربما كان اللفظ مشتركا، والمفسر يعلم أحد المعنيين ويخفى عليه الآخر، وقد يكون هو المراد؛ قال مجاهد: "لا يحل لأحد يؤمن بالله واليوم الآخر أن يتكلم في كتاب الله إذا لم يكن عالما بلغات العرب"(ror). الثالث: النحو والصرف؛ لأن المعنى يتغير ويختلف باختلاف الإعراب، فلا بد من اعتباره؛ وقد سئل الحسن البصري عن الرجل يتعلم العربية يلتمس بها حسن
اشترط العلماء في المفسّر أن يكون ملمًّا بجملة من العلوم التي يستطيع بواسطتها أن يفسّر القرآن تفسيرا مقبولا، وجعلوا هذه العلوم بمثابة أدوات تعصم المفسر من الوقوع في الخطأ، وتحميه دن القول على الله بدون علم، والجمع بين هذه العلوم ممّا لا تقوى عليه همم كثير من المعاصرين، حيث شرطوا أن يلمّ المفسّر بكل العلوم التي هي وسائل لفهم كتاب الله، وأدوات للكشف عن أسراره، فالمفسر لا بد أن يطلب المعنى من كتاب الله، ومن سنّة النبي صلى الله عليه وسلّم؛؛ لأنها مبيّنة للقرآن، فإن أعجزه ذلك رجع إلى أقوال

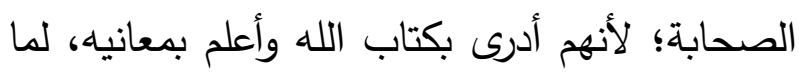
اختصوا به من الفهم التام، والعلم الصحيح، والعمل الصالح، ثمّ يرجع إلى أقوال التابعين؛ لأنهم عاصروا الصحابة وأخذوا عنهم ما حفظوه عن رسول الله صلى الله عليه وسلم، فإن عجز عن هذا كله، ولم يظفر بشيء، فعليه أن يعمل عقله، ويقدح فكره، ويجتها وسعه في الكثف عن مراد الله تعالى، مستندًا إلى إلمامه بالعلوم التي تقدمت. وهذه في حقيقتها شروط الاجتهاد نفسه، لذلك نجد أن من تصدّر للتصنيف في التفسير من السلف كان قد بلغ رتبة الاجتهاد، فلو ذهبنا إلى شيخ المفسّرين ابن جرير الطبري، نجد أنه معدود من جملة المجتهدين، فقد ذكره الثيخ أبو إسحاق الثيرازي في طبقات الفقهاء في جملة المجتهدين. وذكر العلماء أنه كان له مذهب 
العاثر: علم أصول الفقه: إذ به يعرف كيف يستتبط الأحكام من الآيات ويستدل عليها، ويعرف الإجمال والتبيين، والعموم والخصوص، والإطلاق والتتييد،

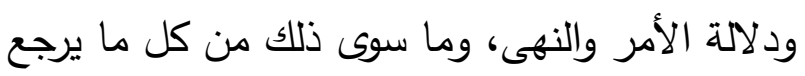
إلى هذا العلم. الحادي عشر: أسباب النزول: إذ إن معرفة سبب النزول يعين على فهم المراد من الآية.

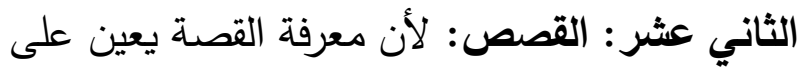
توضيح ما أجمل منها في القرآن. الثالث عثر: علم الناسخ والمنسوخ: وبه يعلم المحكوم من غيره. ومن فقد هذه الناحية، ربما أفتى بحكم منسوخ فيقع في الضلال والإضلال.

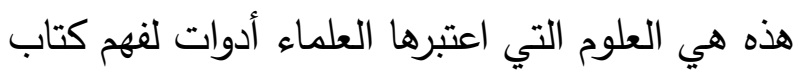

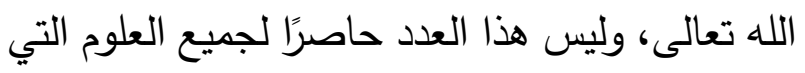
يتوقف عليها التفسير ، فهناك علوم أخرى يحتاج إليها المفسّر غير ما ذكره المتقدّمون منها:

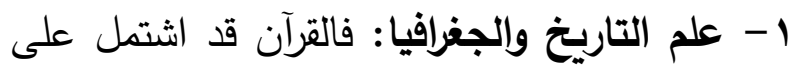
أخبار الأمم الماضية وسيرهم وحوادثهم، وهي أمور تقتضي الإلمام بعلم التاريخ؛ لمعرفة العصور التي

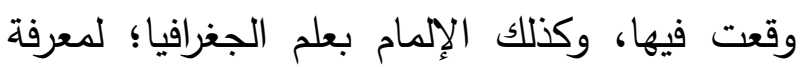
الأمكنة التي وجدت فيها تلك الأمم، ووقعت فيها هذه

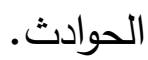
r- علم اللغة التاريخي: وهو علم حديث جدًّا، يبحث تغيّر معنى اللفظ من زمن إلى زمن، وأهميّة ذلك العلم

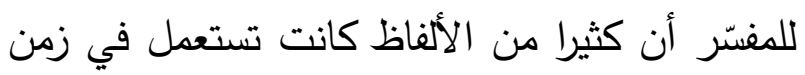

المنطق ويقيم بها قراءته فقال: "حسن فتعلمها، فإن

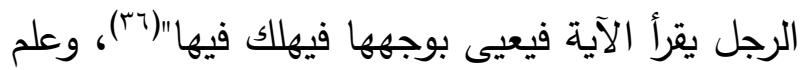
الصرف بواسطته تعرف الأبنية والصيغ (†V) الرابع: الاشتقاق: لأن الاسم إذا كان اشتقاقه من

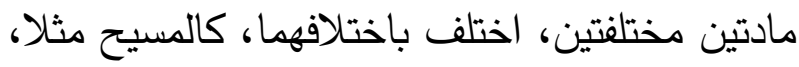

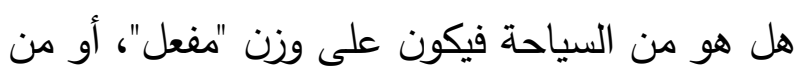
المسح فيكون على وزن "فعيل". الخامس والسادس والسابع: علوم البلاغة الثلاثة "المعاني، والبيان، والبديع": فعلم المعاني، يعرف به خواص تراكيب الكلام من في لمن

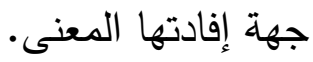
وعلم البيان، يعرف به خواص التراكيب من حيث اختلافها بحسب وضوح الدلالة وخفائها. وعلم البلبي، يعرب به وجوه تحسين الكلام.

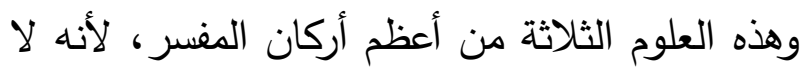

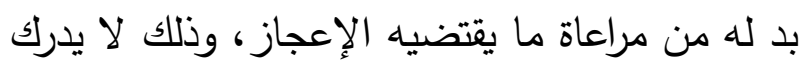
إلا بهذه العلوم. الثامن: علم القراءات: إذ بمعرفة القراءة يمكن ترجيح بعض الوجوه المحتملة على بعض. التاسع: علم أصول الدين: وبه يستطيع المفسر أن لن بعن يستدل على ما يجب في حقه تعالى، وما يجوز ، وما

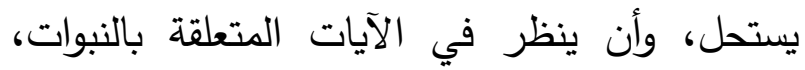
والمعاد، وما إلى ذلك نظرة صائبة، ولولا ذلك لوقع المفسر في ورطات. 
؟ - علم الاجتماع، فقد أنزل الله سبحانه القرآن، وبين

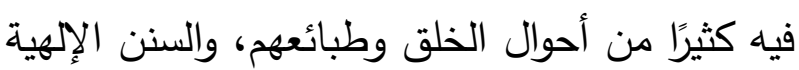

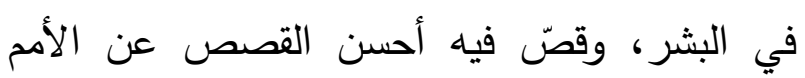
وسيرها الموافقة لسنته فيها، فلا بد للناظر في القرآن

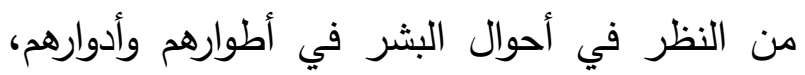
واختلاف أحوالهم من قوة وضعف، وعزّ وذلّ، وعلم

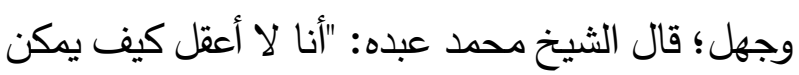

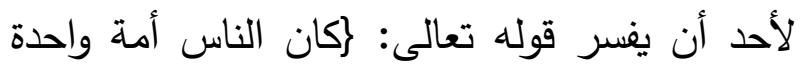

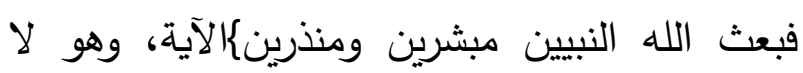
يعرف أحوال البشر، وكيف اتحدوا، وكيف تثرّقوا، وما معنى تلك الوحدة التي كانوا عليها، وهل كانت نافعة أو ضارة، وماذا كان من آثار بعثة النبيين فيهر"(^^").

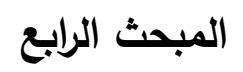

ضرورة إحياء العلم وبعثه وأسباب الحاجة إليه تطور العقل البشري مع التطور المادي: التطوّر سمة أساسيّة للإنسان في كل مناحي الحياة، في الماضي كنا نركب الدواب ونحمل عليه أثقالنا في

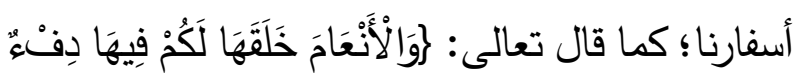

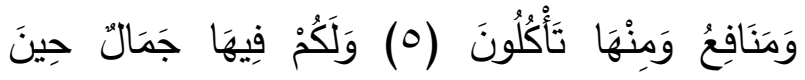

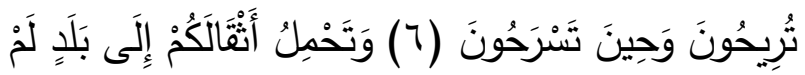

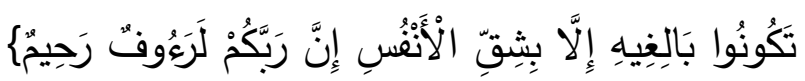

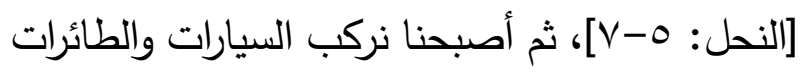

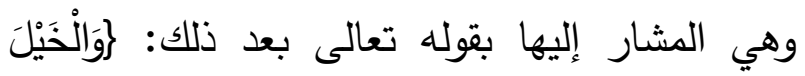

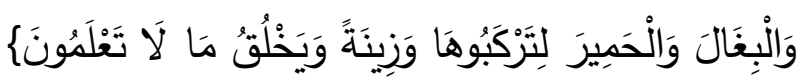

التنزيل لمعانٍ ثم صارت تستعمل لمعانٍ غيرها بعد ذلك بزمن قريب أو بعيد، من ذلك لفظ: "الكلمة"، اشتهر منذ القرن الثاني الهجري بمعنى اللفظ المفرد المنقسم إلى اسم وفعل وحرف، ولكنه جاء في القرآن

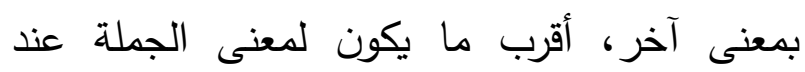

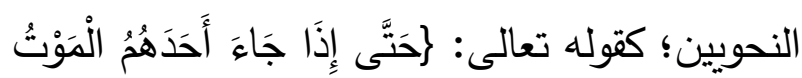

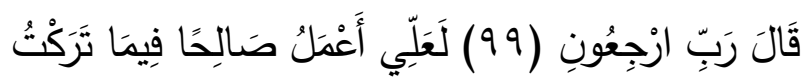

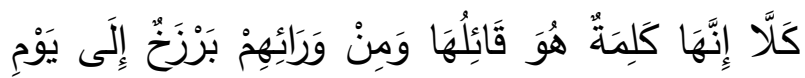

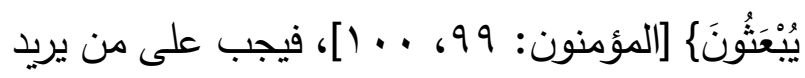
التفسير أن يتتبع الاصطلاحات التي حدثت بعد عصر

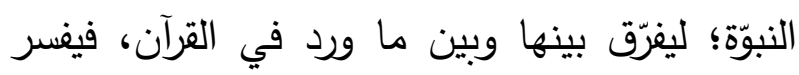
القرآن بحسب المعاني التي كانت مستعملة في عصر نزوله.

ץ- علم الأساليب، فينبغي أن يكون المفسّر عنده من العلم بها ما يفهم به القرآن، وذلك يحصل بممارسة لاندان

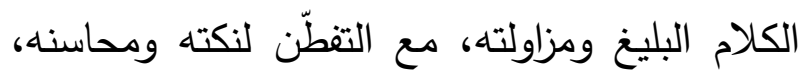

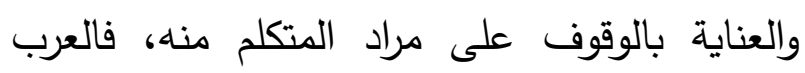
الأوائل كانوا مسدّدين في النطق، يتكلّمون بما يوافق مالق القواعد النحوية قبل أن تُوضع، ولم يكن ذلك أمرًا وراثيًّا أو طبعيَّا كما يظنّه بعض الناس، بل هي ملكة مكتسبة

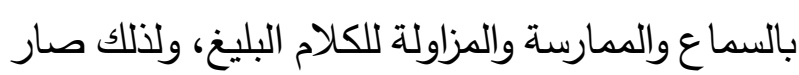

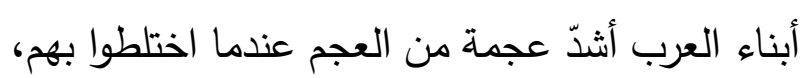

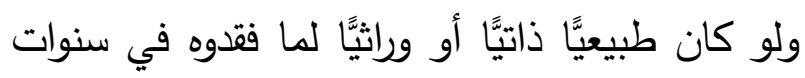
معدودات بعد عصر الصحابة.

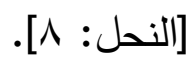


ومع تباعد الناس عن اللغة العربية، أصبحت الحاجة ملحّة لمن يتعلّم هذه اللغة، ويتقنها، مع الأخذ بحظّ من كل علم ليستطيع أن يفهم القرآن ويفهّمه إلى غيره. لكلّ عصر إلى مفسر: يتّضح لنا مّما تقدّم أن عقليّة الإنسان أصبحت أكثر تفتًّا واستيعابًا من ذي قبل بسبب التطوّر الماديّ الهائل في العصر الحديث، وفي المقابل أصبح الناس دئس بعيدين عن فهم القرآن بسبب بعدهم عن اللغة العربية وهي لغة القرآن التي نزل بها. ومما لا شك أن هذا التطور يحتاج إلى التماهي فيه، ترله التهان ويحتاج إلى وجود علماء يفهمون آليّات هذا النطوّر،

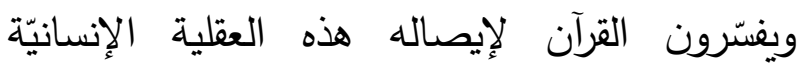

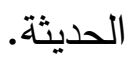
كذلك بعد الناس عن اللغة العربية يحتّم وجود علماء يتقنون اللغة العربية بجميع فروعها؛ كي يفسرون القرآن للناس على قدر أفهامهم وثقافاتهم. وبذلك يتّضح لنا كم يحتاج هذا العصر إلى مفسرين جدد يفهمون آليّات هذا التطوّر الهائل، وفي الوقت نفسه يتقنون اللغة العربية بجميع فروعها، مع استيعاب لجميع علوم الثريعة من حديث وفقه وعقيدة وأصول

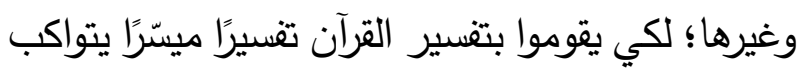
مع تطوّر العصر الحديث، ويصل إلى هذه العقلية الإنسانيّة الحديثة. فيجب علينا أن نبعث المفسرين من جديد، وأن نُحيي هذا العلم، وهذا يوضح أن الناس بحاجة إلى مفسر

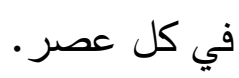

كذلك المعارف كانت ضيّةة، فالإنسان لا يعرف إلا قريته وما حولها، ولا يكاد يعرف من العلم المادي شينًا،

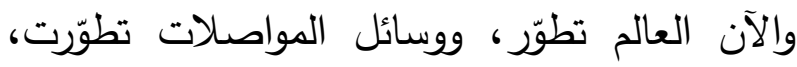
وكذلك وسائل المعرفة ووسائل الإعلام ووسائل التواصل الاجتماعي حتى أصبح العالم كلّه قرية صغير ، وأصبح الإنسان منفتح على كل ما في العالم من اختلاف اللغات والثقافات، وتداخل الثقافات مع ول بعضها. كلما تباعد الزمان بعد الناس عن فهم القرآن: كذلك هذا التطور يصاحبه تباعد الزمان؛ الذي ترتبّ لتب عليه تباعد الناس عن اللغة العربية وبالتالي ترتّب عليه بُعد الناس عن فهم القرآن الذي لا يفهمه إلا مَن كان

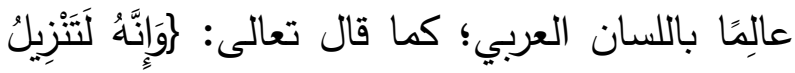

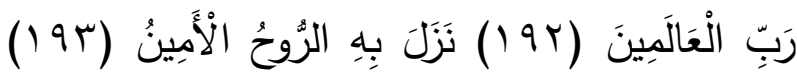

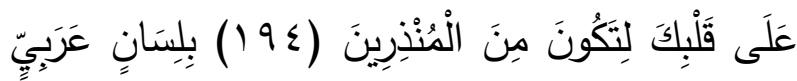

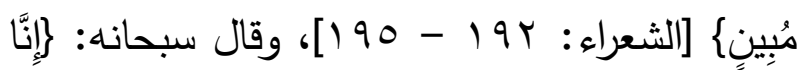

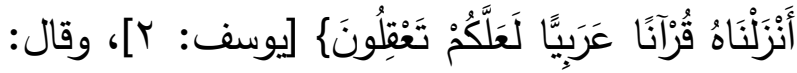

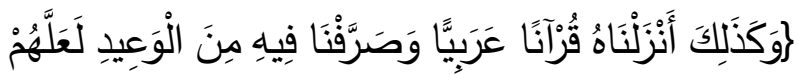

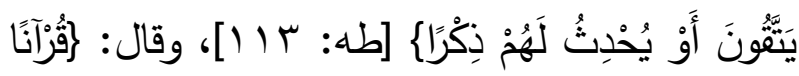

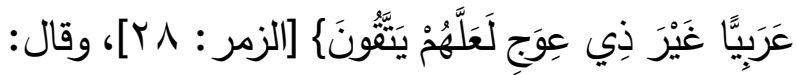

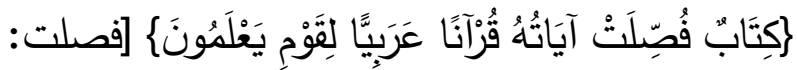

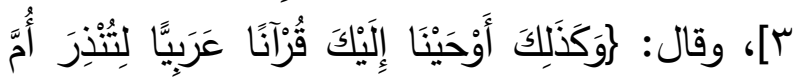

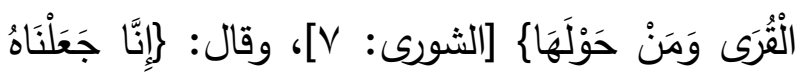

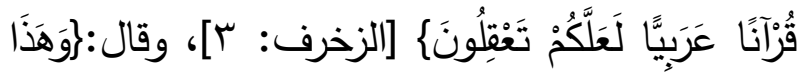

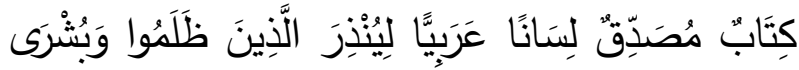
لِلُْحْمِنِيِ 
صلى الله عليه وسلم لابن عباس بالدعاء لله بقوله:

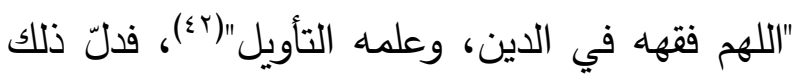
على أن التأويل أمر آخر وراء النقل والسماع، وذلك وعلك هو التقسير بالاجتهاد الناشئ عن وجود تلك الملكة والموهبة، وهذا بيّن لا إثكال فيه. ولا شكّ أن متقدمي المفسرين قد توسعوا في التفسير إلى حد كبير، جعل من جاء بعدهم يزهد في الكتابة

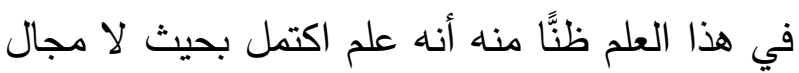
للزيادة عليه، ممّا أدّى إلى ضعف فلى ملكة التفسير عندهم، وقد تجلّى ضعف ملكة التفسير في العصر الحديث في عدة مظاهر ، منها: ا - ندرة المؤلفات في التفسير في العصر الحديث:

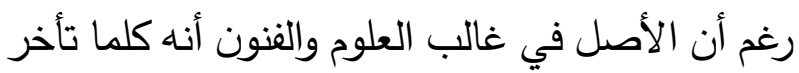
الزمان توسّع العلماء في التصنيف في تلك الفنون والعلوم، وتتاولوا مصنفات المتقدمين بالثرح والتحشية لرية والزيادة، وأشهر مثال على ذلك علم الفقه، حيث نجد مصنفات المتأخرين فيه تفوق مصنفات المتقدمين

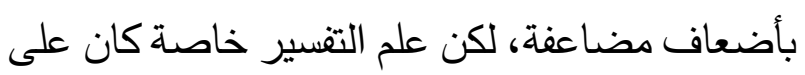
الخلاف من ذلك، حيث قلّت المصنفات فيه في لئي العصر الحديث بصورة واضحة. r - ضعف المحتوى العلمي للمصنفات في التفسير

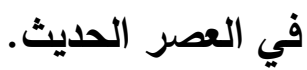
لم تكن قلة المصنفات في التفسير في العصر الحديث هي المظهر الوحيد لضعف ملكة التقسير في العصر

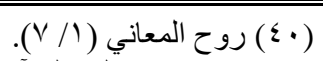

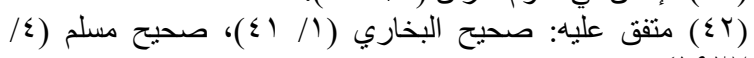

المبحث الخامس

مظاهر ضعف ملكة التفسير في العصر الحديث

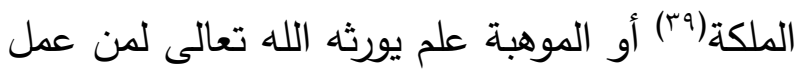

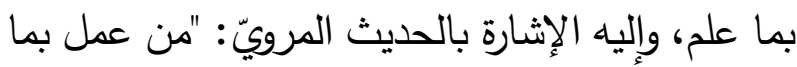

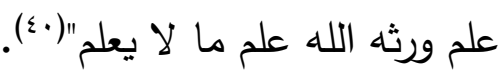
وقد يقول بعض الناس: إن الملكة الموهبة شيء خارج عن القدرة فكيف يُذكر كسبب لندرة المفسرين في العصر الحديث؟ وقد ردّ السيوطي على هذه الثبهة بعد أن عدّ علم الموهبة من العلوم التي لا بد منها للمفسر فقال: "ولعلك تستشكل علم الموهبة وتقول: هذا شيء ليس في قدرة الإنسان. وليس الأمر كما ظننتَ

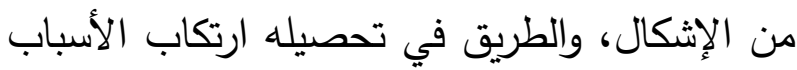

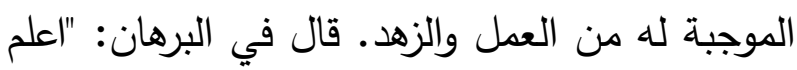
أنه لا يحصل للناظر فهم معاني الوحي ولا تظهر له

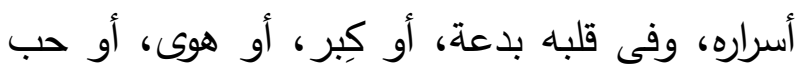

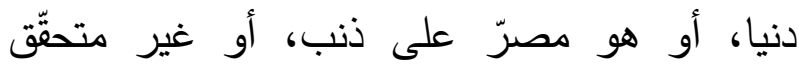

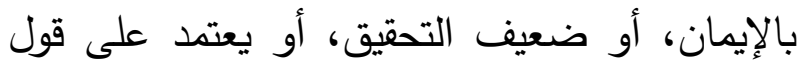
مفسّر ليس عنده علم، أو راجع إلى معقوله، وهذه كلها

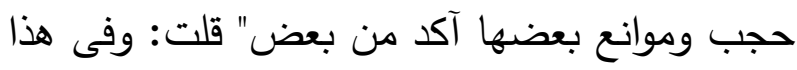

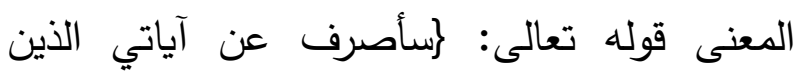

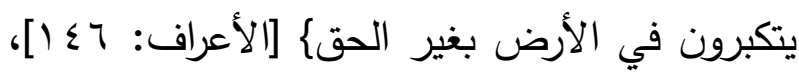

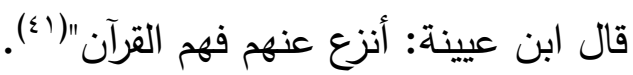

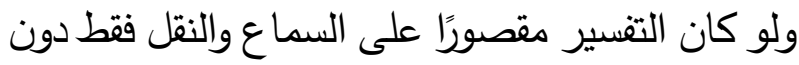
حاجة لموهبة، لما كان هناك فائدة لتخصيص التصول النبي

(T) المَلَكَّة: صفة راسخة في النفس، تحصل بسبب فعل من الأفعال،

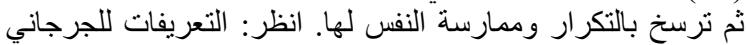

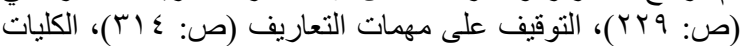

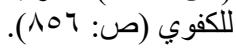


ما شاء منها بضغطة زرّ، دون حاجة إلى السفر والرحلة، ولا حمل الأسفار وتقليب الصفحات. لكن واقع الحال يبيّن أنّ الأمر يرجع إلى غياب الحافز ولئ

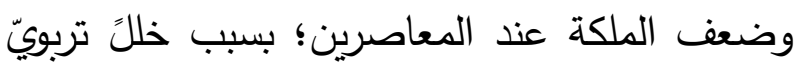
عند الأجيال الناشئة في مجتمع ماديّ لا يعترف بقيمة الفكر والتفكّر والتدبّر ، والتفسير ما هو إلا وسيلة لتدبّر

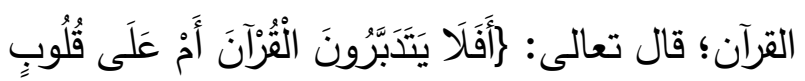

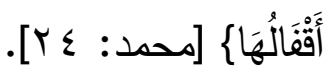

لذلك يمكن أن نستلهم الأسباب التي أدّت إلى ضعف التف

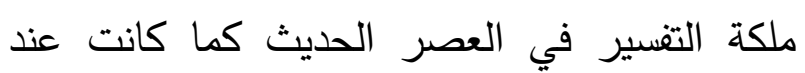
الأوائل كالتالي:

1- اعتقاد بعض طلبة العلم أن علم التفسير قد نضج

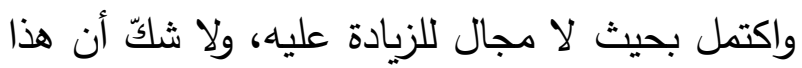
اعتقاد خاطئ؛ لأن عقليّة الإنسان أصبحت أكثر تفتًِّا واستيعابًا من ذي قبل بسبب التطوّر الماديّ الهائل في الإني

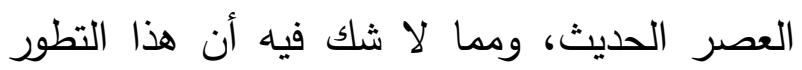
يحتاج إلى التماهي فيه، ويحتاج إلى وجود علماء يفهمون آليّات هذا التطوّر، ويفسّرون القرآن لإيصاله

$$
\text { إلى هذه العقلية الإنسانيّة الحديثة. }
$$

r- عدم اهتمام الأسر بعلم التفسير وتعليمه لأبنائهم،

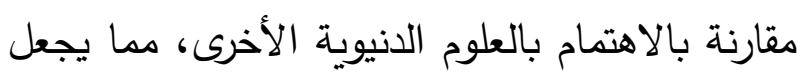
الأجيال القادمة تزهد في هذا العلم الجليل. r- ضعف اللغة العربية عند غالب الدارسين للعلوم لهاني الشرعية ومنها التفسير، والقرآن نزل بلسان عربي التعبي مبين، فلا مجال لفهمه وتفسيره إلا لمن كان عالمِّا
الحديث، بل صاحب ذلك ضعف المحتوى العلمي فيما

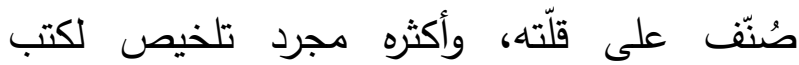
المتقدمين أو محض نقل منها بلا تحرير ولا تنقيح، حتى أصبح علم التفسير بعيدا عن مواكبة التطور البشري والحضاري الذي هو أهم سمات هذا العصر . r- الاعتماد الواضح في النقل الحرفي لبعض من لهن كتبوا في التفسير في العصر الحديث: وهذا الأمر لاعري أصبح ظاهرة وسمة عامّة لغالب المؤلفات في العلوم

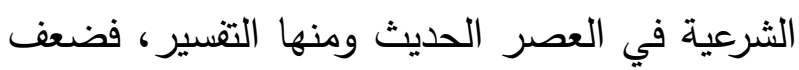
الموهبة وغياب الملكة مع خوض غير المؤهلين غمار التأليف بغير علم ولا دراسة أدّى إلى اعتماد هؤلاء

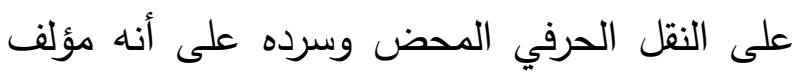
جديد، كما يقال: (انقل من هنا ومن هنا وقل ألّفته أنا)، وفي دعاء النبي صلى الله عليه وسلم لابن

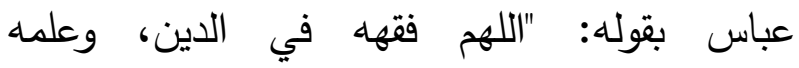

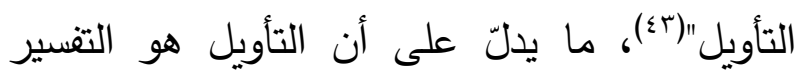
بالاجتهاد الناشئ عن وجود الملكة والموهبة، وليس مجرد النقل الحرفي الذي يحسنه كل أحد. المبحث السادس لئاس

\section{أسباب ضعف ملكة التفسير في العصر الحديث}

قد يستغرب بعض الناس من غياب المفسّرين في العصر الحديث مع وجود التقنيات الحديثة التي تخدم التفسير ، وتيسّر على المفسّر ما كان عسيرًا على

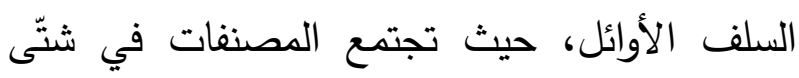
العلوم أمامه في مكان واحد يستطيع أن يحصل على لهي 
تلك الدول كالدعوة لإحياء الأمازيغية في دول المغرب العربي، والعمل على جعلها اللغة الرسمية للبلاد.

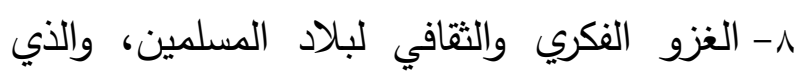
يهدف في الأساس إلى إبعاد المسلمين عن كتاب الله لهابل تعالى، حيث وجد الغرب أن القضاء على القرآن محال

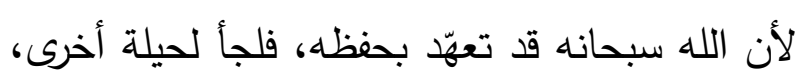
وهي الفصل بين المسلمين وبين القرآن بعد فهم معانيه

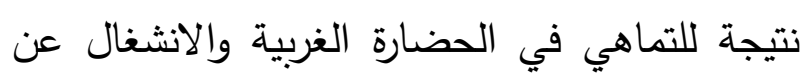
تقسير القرآن وفهمه. 9- ضعف تركيز الجامعات والمؤسسات العلمية على ولى علم التفسير ، وعدم إعطائه حقّه من التدريس والتعليم والتتمية.

• 1- فساد النية عند كثير من الدارسين لعلم التفسير،

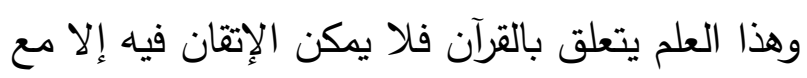
الإخلاص وصلاح النية. 11- الطفرة العلمية الحديثة وسهولة الوصول وليهل للمعلومات من خلال الإنترنت، وهو ما سبّب زهدًا في

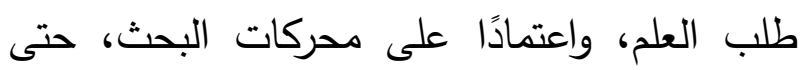
أضحى بعض طلبة العلم يتوهم أن صرف الوقت في طلب العلم هدر لا طائل تحته ولا جدوى علمية منه. r ا - الهزيمة النفسية عند طلبة العلوم الثرعية عامّة وعلم التفسير خاصّة، وعدم رفع الرأس والاعتزاز بالعلم

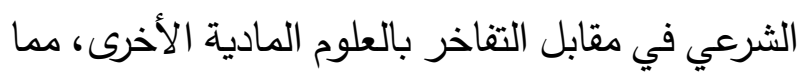

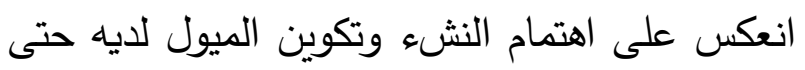

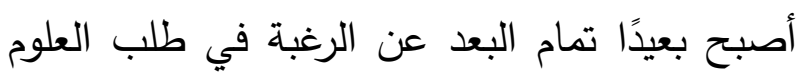
الشرعية وعلى رأسها علم التقسير .

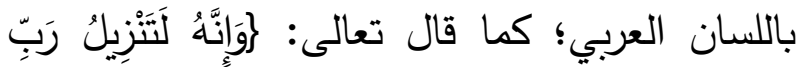

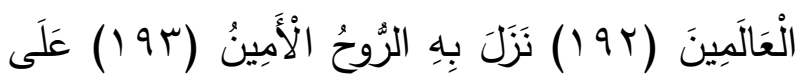

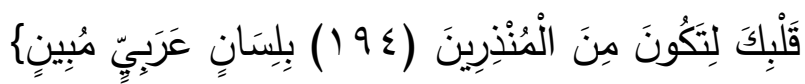

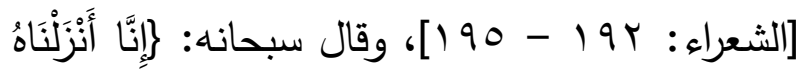

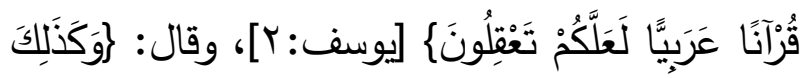

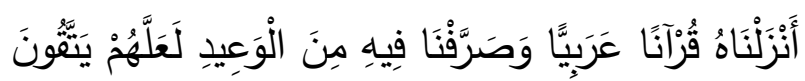

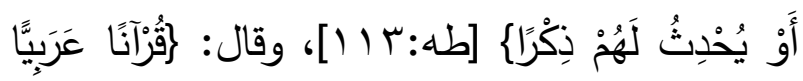

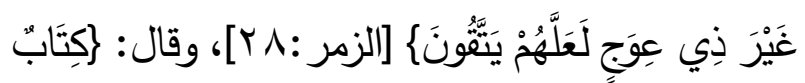

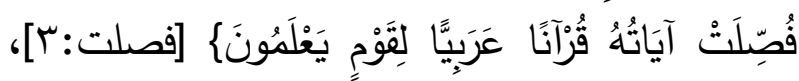

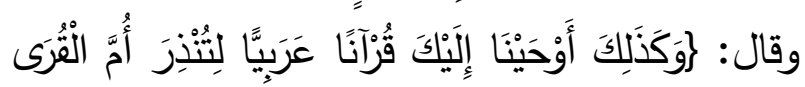

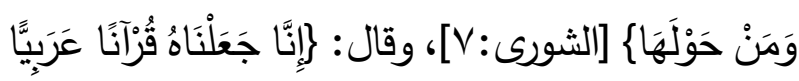

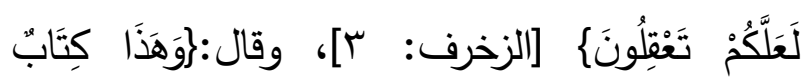

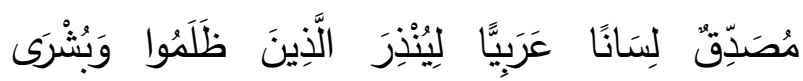

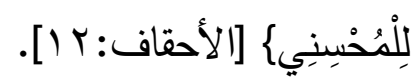
ع- استخدام العامية في لغة الخطابة على المنابر وفي المجامع مما زاد من ضعف ملكة اللغة العربية عند العائه طلبة العلم المعاصرين. ه- سيطرة العامية على الإعلام في غالب الدول

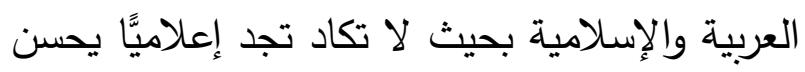
النطق باللغة العربية فضلا عن أن يتقنها. צ- تحوّل العامية إلى لغة الحوار والنقاش بين أبناء

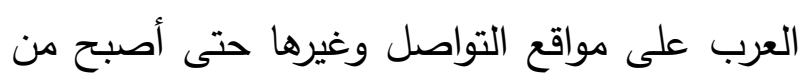
يكتب باللغة العربية على هذه العابت المواقع يقابل بالاستهجان والسخرية. V - الدعوات إلى إحياء اللهجات الإقليمية الخاصة في ولئه بعض الدول العربية وجعلها لغة الكتابة والتأليف في لإلياء 
سץ- ضعف مهارات البحث العلمي لدى طلبة العلم فلا يمكنهم تحصيل المادة اللازمة للمضي قُدُمًا في التفسير

ع - احتقار النفس والتقليل من شأنها مما يضعف الهمّة عن تحصيل العلم فضلًا عن الإبداع فيه. هـ- المعاصي المانعة للفتح والفهم، وإن المرء يُحرم

\section{الخير بالمعصية يقع فيها.}

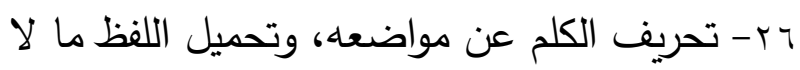
يحتمل عند تفسيره، فينشأ عن ذلك أقوال في التفسير لم يسبق إليها أحد من أهل العلم ولا دليل عليها، بل قد يدلّ الدليل على ضدّها. rV - ضعف الاستشهاد بالقرآن لدى كثير من الدارسين مما يقطع العلاقة بينهم وبين القرآن وفهمه وتفسيره. ^ץ - قلة دروس التقسير المقامة في المساجد والمعاهد ونحوها. وץ- الفهم السطحي الظاهري لألفاظ القرآن دون التعمّق في فههها وتدبّرها. • r- غياب ربط القرآن بالواقع ممّا أنشأ حاجزًا بين. فهنا للقرآن وتطبيقه في حياتنا وهو أساس علم التفسير

اس- الجمود على كتب معينة في كلّ فنّ، مدّا يعطّل

$$
\text { الذهن عن التوسّع في الفهم والتدبّر . }
$$

rr- النقل المحض دون تمحيص أو تحليل ممّا يقتل

$$
\text { ملكة الإبداع عند طالب العلم. }
$$

rr- انتشار الشبهات وتقبّلها بسهولة، وهو ما يُغلق

$$
\text { أبواب الفهم عند طلبة العلم. }
$$

rا- ندرة المربين والموجهين لطلاب العلم الذين يعينونهم على اكتشاف مواهبهم وملكاتهم وميولهم في التفسير وغيره من العلوم الثرعية ومساعدتهم في ذلك. ع ا - ضعف التحفيز المجتمعي والمدرسي على أهمية العناية بكتاب الله وبعلوم القرآن وعلى رأسها تقسير القرآن. 1 - ضعف منهجية حلقات التحفيظ ومدارس التحفيظ وجمعيات التحفيظ حيث تصبّ تركيزها على حفظ القرآن فقط دون وجود خط موازٍ يهتم بتقسير كتاب الله تعالى للدارسين. 1 ا - انحدار المستوى اللغوي لدى الكثير من طلاب

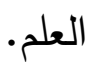
IV - ضعف تعظيم القرآن في القلوب مما أضعف الهمة للاشتغال بتفسيره وفهمه. 11- ضعف ملكة الإبداع لدى طلبة العلم، وملكة التقسير قوامها الإبداع. 9 1 - إغلاق باب الاجتهاد والاتكال على ما ورد وصُنف في غالب العلوم وعلى رأسها علم التفسير • • r- ندرة النقاش المثري بين الدارسين والباحثين الذي أدّى إلى عدم وجود ملامح للتجديد لديهم. اr- التعصب للجماعة أو المذهب الذي يغلق على وجلى الدارس باب الإبداع والتجديد. r الاشتغال باللفظ دون المعنى، فيتحول علم التفسير إلى مجرد درس لغوي. 
ع - الدعوة إلى تبنّي المؤسسات العلميّة وضع مناهج

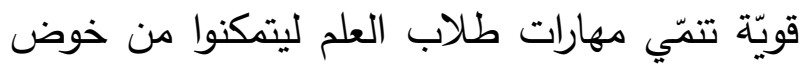
غمار تقسير القرآن. ه- إضافة حلقة مدارسة لتفسير القرآن أسبوعيًّا إلى لقي حلقات تحفيظ القرآن في المساجد والمعاهد ونحوها. צ- استكتاب الباحثين في دراستهم لعلم التنسير •

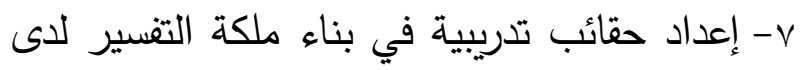
الدارسين. ^- وضع آليّة أو برنامج عملي في المعاهد والجامعات لإعداد طالب علم التفسير. 9- تأهيل مدربين لبناء ملكة التفسير عند طلاب العلم وتوفير كافة السبل لتفريغهم لذلك. • 1- استكشاف النوابغ مبكرًا في المدارس خاصّة النوابخ في فهم القرآن وتأهيلهم ليكونوا مفسّرين للقرآن. 1 - إهتمام مؤسسات التعليم بعلم التفسير كأحد أهم ركائز علوم الشريعة. rا - تأهيل نماذج إعلامية تقدم النموذج الصحيح في تفسير القرآن للجمهور، ومن أشهر النماذج المعاصرة في ذلك فضيلة الثيخ الشعراوي رحمه الله. rا - إقامة مسابقات دورية في تفسير القرآن على غرار مسابقات حفظ القرآن وتكون على كافة المستويات

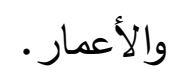
ع ا - تأسيس دبلوم خاص يسمى دبلوم صناعة المفسر

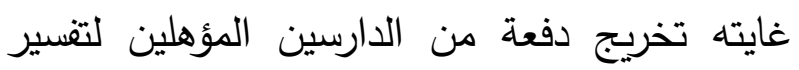
القرآن. ؟r- التعاطي العاطفي مع معاني القرآن، وهذا يتناقض مع المنهج العلمي الذي يقتضيك فهم القرآن وتفسيره. هب- تحميل القرآن ما لا يحتمل من المعاني والتأويلات الباطلة.

\section{المبحث السابع}

وسائل علاج ضعف ملكة التفسير في العصر

$$
\text { الحديث }
$$

من خلال التعرّف على أسباب ضعف ملكة التفسير في العصر الحديث يمكننا أن نستشف الوسائل التي يمكن بها علاج ذلك الضعف، وذلك بما يلي:

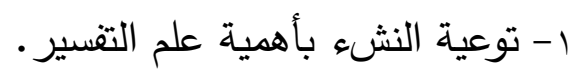
r- توعية المجتمع والأُسَر بأهمية علم التفسير. r- تتمية ملكة الإبداع لدى طلبة العلم، وملكة التفسير

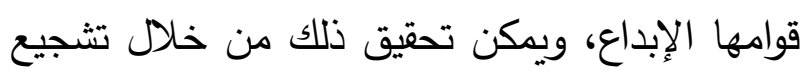
الطلاب على الاجتهاد في تفسير بعض الآيات عن ون الإبن طريق جمع أقوال السلف في تفسير الآية، ثم يجتهد الطالب في تفسير الآية من خلال علمه باللسان العربي والحديث والأثر ، ثم ينظر بعد ذلك في أقوال

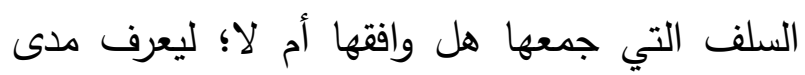
إتقانه لفهم كلام الله تعالى، ومع الوقت والتكرار تزداد نسبة إصابته في التفسير حتى تتمو عنده تلك الملكة فلا يصير في التفسير عالة على غيره، بل يصبح قادرًا على تفسير الآيات بنفسه مع عدم خروجه عن تفسير السلف. 
جاء نصر الله والفتح فتح مكة، فذاك علامة أجلك: فسبح بحمد ربك واستغفره إنه كان توابا. قال عمر: 》ا أعلم منها إلا ما تعلم《( ). 9 - أوجيه طلّاب العلم للاطّلاع على مستجدّات العلم في جميع المجالات والتخصّصات، والقراءة في الكتب والموسوعات العلميّة المختلفة؛ لكي تتّّع مداركهم، وتتمو ملكاتهم التي تعينهم على فهم ما قد يغيب عن غيرهم من دقائق التقسير ولطائف المعاني. • r- الجمع بين المعارف والعلوم الأصيلة وبين مواكبة العصر ، فإن هذا الثرخ الذي وقَع بين المعارف والعلوم الأصيلة وبين مواكبة العصر هو الذي جعل في بعض الأحيان كَن لم يفهموا الإسلام ينعتون العلوم الإسلامية بالركود والرجعيَّة، وعدم جدواها في واقع العولمة والحداثة، وهو مما لا شك أنه نعتُ خاطئ، فالقرآن نزل لهداية الناس أجمعين؛ قال تعالى: رشَهْرُ رَخَضَانَ

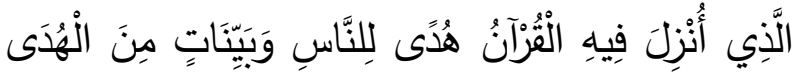

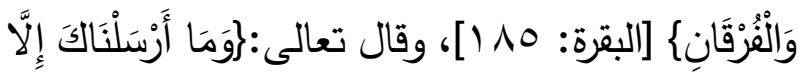

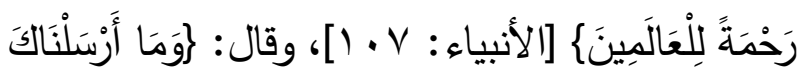

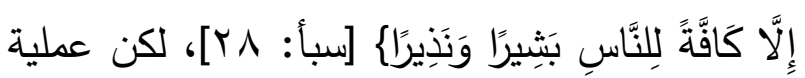
التفسير تتطلق من اتباع مراحل، واعتماد آليات متجسدة في العلوم التي يَنبغي أن يتحلَّى بها المفسِّر؛ من أجل أن يُخرج أسرارَ القرآن وأحكامه وحِكمه، وفوائده ومواعظه وعِبره، التي تَنفع الناسَ في كلِ زمان ومكان، وهذه الأسرار يُلهِمِ اللهُ تعالى لها عبادَه العلماء الذين يَهتدون لها على أساس الاعتماد على تلك المعارف والعلوم، فلتشكيل علم التفسير لا بدَّ من
ه - زرع الثقة المنضبطة في نفوس الباحثين التي تشجّعهم على خوض غمار علم التفسير • 7 ا - تتمية المهارات اللغوية عند طالب العلم؛ وذلك بكثرة قراءة تراث العرب الأوائل من شعرٍ ونثرٍ ، وحفظ بعض عيون القصائد كالمعلّات وأشعار الحماسة، وفهم معاني ألفاظها، ومطالعة كتب الأدب والبلاغة، وغريب القرآن والحديث؛ ليكتسب ثروة لغويّة تعينه على فهم كتاب الله، وتدبّر آياته. IV - تشجيع طالب العلم على الثموليّة العلميّة، بحيث يضرب في كلّ علم بسهمٍ، ولا يقتصر على مجال تخصّصه فقط؛ لكي يستطيع أن يحقّق شروط المفسّر التي اتفق عليها العلماء.

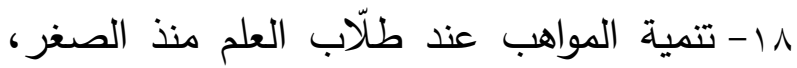
ومنحهم الثقة بأنفسهم، ودمجهم في مجالس الكبار من أهل العلم، وعدم التقليل من شأنهم لصغر سنّهم؛ فعن ابن عباس رضي الله عنهما، قال: كان عمر يدخلني مع أشياخ بدر، فقال بعضهم: لم تدخل هذا الفتى معنا ولنا أبناء مثله؟ فقال: 》إنه ممن قد علمتم/ قال: فدعاهم ذات يوم ودعاني معهم قال: وما رأيته دعاني يومئذ إلا ليريهم مني، فقال: ما تقولون في إذا جاء نصر الله والفتح، ورأيت الناس يدخلون في دين الله أفواجا حتى ختم السورة، فقال بعضهم: أرنا أن نحمد الله ونستغفره إذا نصرنا وفتح علينا، وقال بعضهه: لا ندري، أو لم يقل بعضهح شيئا، فقال لي: يا ابن عباس، أكذاك تقول؟ قلت: لا، قال: فما تقول؟ قلت: هو أجل رسول الله صلى الله عليه وسلم أعلمه الله له: إذا 
^ץ- محاربة استخدام العامية في لغة الخطابة على المنابر وفي المجامع، وتقوية ملكة اللغة العربية عند الخطباء والأئمة وطلبة العلم المعاصرين. وץ- الدعوة إلى استعمال اللغة العربية في لغة الحوار والنقاش بين أبناء العرب على مواقع التواصل وغيرها ومؤزرة من يقوم بذلك وتشجيعه.

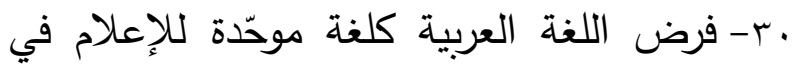
الدول العربية والإسلامية بحيث لا يصرّح للإعلاميّين بمزاولة المهنة إلا إذا كانوا يحسنون النطق باللغة العربية ويتقنون ذلك.

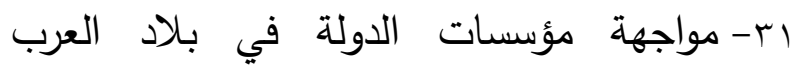
للأصوات الداعية إلى إحياء اللهجات الإقليمية الخاصة بكل بلد وفرض اللغة العربية كلغة موحدة للكتابة والتأليف. بلف.

بr- دعوة الباحثين والدارسين لعلم التفسير إلى تصحيح النية؛ لأن هذا العلم يتعلق بالقرآن فلا يمكن الإتقان فيه إلا مع الإخلاص وصلاح النية.

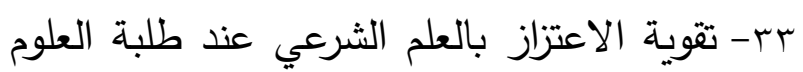

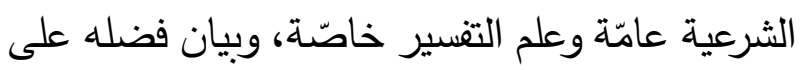
العلوم المادية الأخرى، مما ينعكس على اهتمام النشء

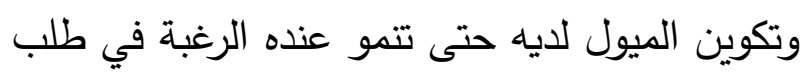

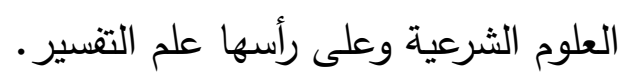
§ ז- تحسين المستوى اللغوي لاى الباحثين والدارسين وطلاب علم التفسير. هץ- فتح باب الاجتهاد أما طلبة العلم والدارسين والباحثين، وبيان الأدوات والعلوم اللازم تحصيلها لبلوغ
الانطلاق من تلك المعارف الأصيلة، ودمجها كلها من أجل فهم القرآن الكريم، ثم بعد ذلك النظر في الواقع المعاصر والمواكبة بينه وبين تلك المعارف؛ لأن الغاية

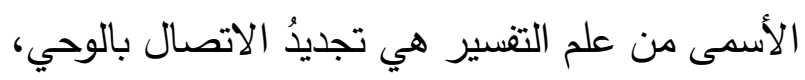
وتعريف العباد على منهجيَّة التلقي للهدى الربَّاني المنزل من السماء ليكون منهج حياة ونبراسًا للمسلمين في جميع العصور • اب-طرح النوازل المعاصرة التي تضطر الباحث

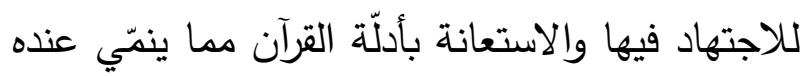
ملكة التقسير • r T - مجابهة الثبهات والقضاء عليها بالدليل العلمي الصحيح، وهو ما يفتح أبواب الفهم عند طلبة العلم.

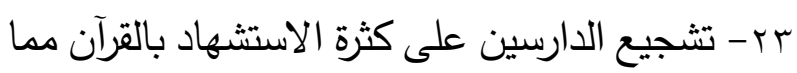
ينمّي العلاقة بينهم وبين القرآن وفهمه وتقسيره.

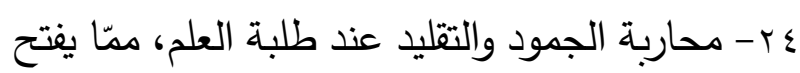
أذهانهم للتوسّع في الفهم والتدبّر . هr- توعية طلبة العلم أن علم التفسير ما زال يحتاج إلى بحث وتتقيب لتشجيعهم على خوض غماره. بr-مواجهة الغزو الفكري والثقافي لبلاد المسلمين بالحجج والبراهين، لإعادة الصلة بين المسلمين وبين القرآن وفهم معانيه. V V- الاهتمام باللغة العربية ودراستها في المدارس ونس والمعاهد والجامعات والمؤسسات العمية؛ لأن القرآن نزل بلسان عربي مبين، فلا مجال لفهمه وتفسيره إلا

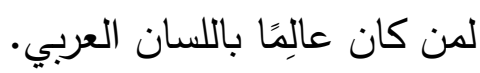


درجة الاجتهاد في غالب العلوم وعلى رأسها علم العلي القدير أن يتجاوز عن زلتي وخطأي، وكل

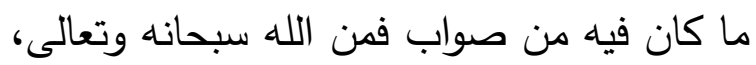
- التقسير

وما فيه من خطأ فمن نفسي ومن الشيطان. ومن أهم النتائج التي توصلت فئ إليها: 1- نثأة علم التقسير كانت مبكرة جدا في حياة النبي صلى الله عليه وسلم بسؤال الصحابة له؛ لأن القرآن فيه المجمل، والمشكل، والمتشابه، وغير ذلك مما لا يكفي فيه مجرد العلم باللغة. r- نشأت مدارس التنسير في أمصار المسلمين نتيجة لتثرّق الصحابة رضوان الله عليهم في جميع التحني البلاد التي دخلها الإسلام، ولم يستقروا جميعا في

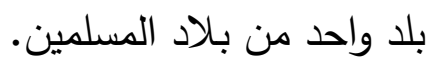
r- أشهر مدارس التقسير في عهد الصحابة والتابعين كانت: مدرسة التتسير بمكة، وكان قيام هذه المدرسة على عبدالله بن عباس رضي الله عنهما، ومدرسة التفسير بالمدينة، وكان قيام هذه

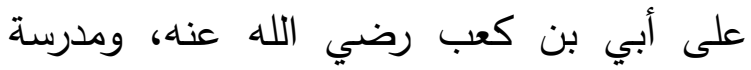
التتسير بالعراق، وكان قيام هذه المدرسة على عبد الله بن مسعود رضي الله عنه. ع- يعتبر علم التفسير من أوائل العلوم التي نضجت في عهد مبكر جدًّا يتّصل بعصر الصحابة الصنية أنفسه؛ لذلك ليس من السهل أن نعيّن من سبق إلى وضع مصنّف مستقل في تنسير القرآن على سلى

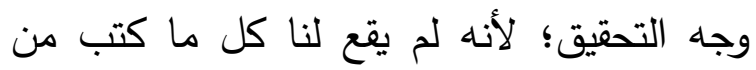
التقسير من مبدأ عهد التدوين. بr- إثراء النقاش العلمي بين الدارسين والباحثين مما يظهر ملامح التجديد لايهم. rV دعوة الباحثين والدارسين وطلبة العلم إلى نبذ التعصب للجماعة أو المذهب الذي يغلق عليهم باب الإلبداع والتجديد. ^ץ- دعوة الباحثين والدارسين وطلبة العلم إلى الى الاشتغال بالمعاني مع المباني، حتى لا يتحول علم التقسير إلى مجرد درس لغوي مجرد عن المعنى.

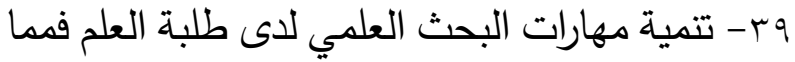

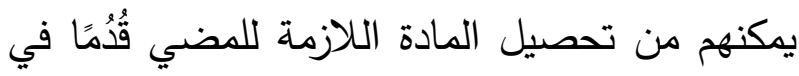
• التفسير •ـ - موعظة الدارسين والباحثين وطلبة العلم بترك المعاصي المانعة للفتح والفهم؛ لأن المرء يُحرم الخير بالمعصية يقع فيها. اء - الدعوة إلى التعمّق في فهم القرآن وعدم الاقتصار على الفهم السطحي الظاهري للألفاظ. r ؟ - ربط القرآن بالواقع ممّا ينشئ جسرًا بين فهمنا

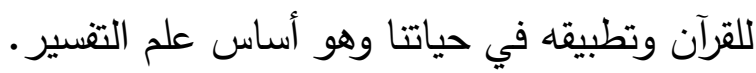
الخاتمة

الحمد لله الذي بنعمته تتم الصالحات، والصلاة والسلام على سيدنا محمد وعلى آله وأصحابه وذريته ومن والاه، الحمد لله حمدًا كثيرًا طيبًّا كما يحب ربي ويرضى لما وفقني وأنعم علي سبحانه وتعالى به من حسن إتمام هذا البحث، وأسأل الله 
r- توفير وسائل للنهوض بعلم التفسير في العصر الحديث، منها على سبيل المثال: تتمية المهارات اللغوية عند طالب العلم، وتثجيع طالب العلم على سلى لكي الثموليّة العلميّة، وتتمية المواهب عند طلّاب العلم منذ الصغر، وتوجيه طلّاب العلم للاطّلاع على العى

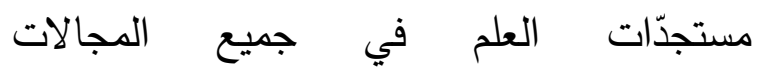
والتخصّصات، وتثجيع طلاب العلم على تتمية ملكة التقسير عندهم، والجمع بين المعارف والعلوم

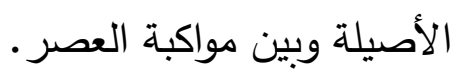
فهرس المصادر والمراجع 1- الإتقان في علوم القرآن، المؤلف: عبد الرحمن

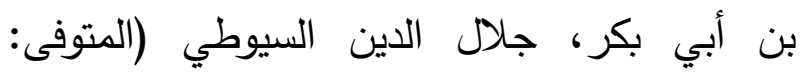
(1) به)، المحقق: محمد أبو الفضل إبراهيم، الناشر:

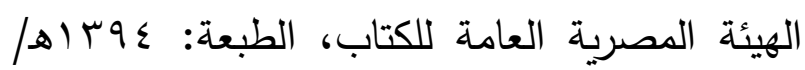
. $19 \vee \varepsilon$

r- البحر المحيط في التفسير، المؤلف: أبو حيان محمد بن يوسف بن علي بن يوسف بن حيان أثير

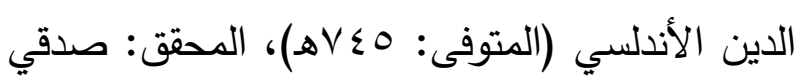

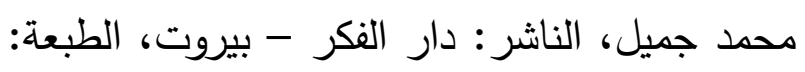
. r- البرهان في علوم القرآن، المؤلف: أبو عبد الله

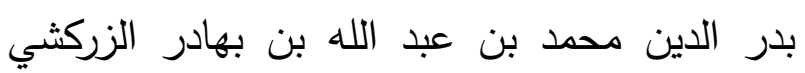

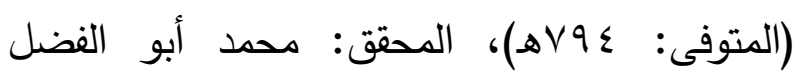

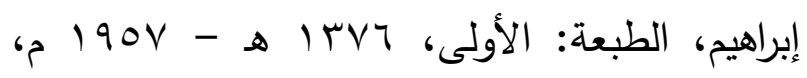
الناشر : دار إحياء الكتب العربية عيسى البابي الحلبي وشركائه.
0- يمكن تقسيم المصنّفات في التفسير بحسب الطريقة المتّبعة في التقسير إلى قسمين كبيرين

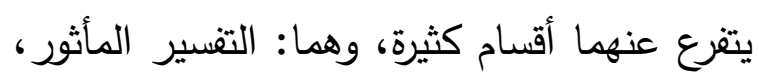
والتفسير بالرأي. 4- توسّع متقدمي المفسرين في التفسير إلى حد كبير، جعل من جاء بعدهم يزهد في الكتابة في

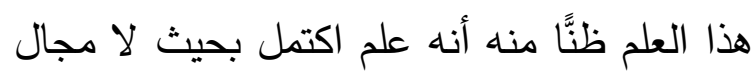

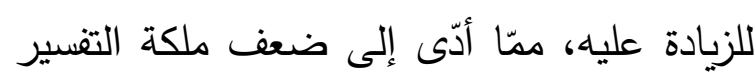
عندهم. V - السبب الحقيقي لانصراف المعاصرين عن الخوض في تقسير القرآن هو اشترط العلماء إلمام المفسّر بجملة من العلوم تضعف همم المعاصرين عن تحصيلها مجتمعة، مع غياب الملكة والموهبة. التوصيات

ا- مع تباعد الناس عن اللغة العربية، وتطور

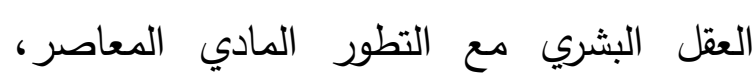
أصبحت الحاجة ملحّة إلى مفسرين جدد يفهون آليّات هذا التطوّر الهائل، وفي الوقت نفسه يتقنون اللغة العربية بجميع فروعها، مع استيعاب لجميع علوم الثريعة من حديث وفقه وعقيدة وأصول وغيرها؛ لكي يقوموا بتقسير القرآن تفسيرًا ميسّرًا

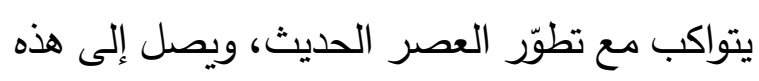
العقلية الإنسانيّة الحديثة. r- بعث المفسرين من جديد، وإحياء هذا العلم،

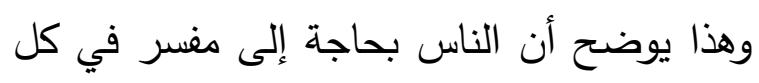


9- تفسير الطبري، المؤلف: محمد بن جرير بن يزيد بن كثير بن غالب الآملي، أبو جعفر الطبري

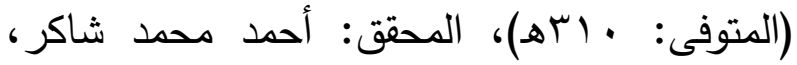

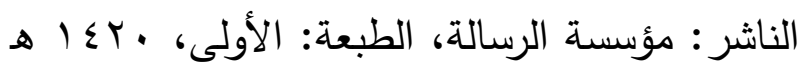
. ${ }^{2}+\ldots-$ ـ 1 - تفسير الماتريدي، المؤلف: محمد بن محمد بن محمود، أبو منصور الماتريدي (المتوفى: سبسه)، المحقق: د. مجدي باسلوم، الناشر : دار الكتب العلمية

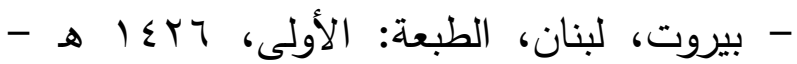

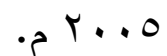

1 - التفسير المأمون على منهج التنزيل والصحيح

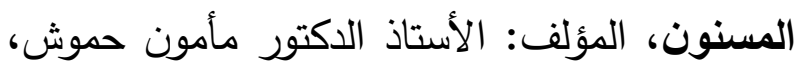
المدقق اللغوي: أحمد راتب حمش، الناشر:

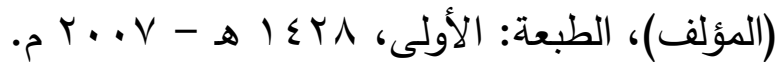

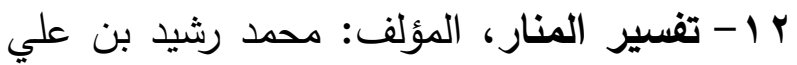
رضا القلموني الحسيني (المتوفى: عهب اهـ)، الناشر : الهيئة المصرية العامة للكتاب، سنة النشر : . 199 م. r ا - التفسير والمفسرون، المؤلف: الدكتور محمد السيد حسين الذهبي (المتوفى: 9 ب اهـ)، الناشر: مكتبة وهبة، القاهرة. ع ا- جامع بيان العلم وفضله، المؤلف: أبو عمر يوسف بن عبد الله بن محمد بن عبد البر بن عاصم

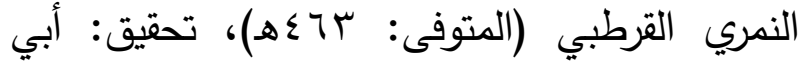
الأشبال الزهيري، الناشر: دار ابن الجوزي، المملكة الهرئ

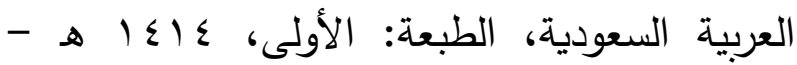
. $199 \varepsilon$
ع- تاريخ ابن أبي خيثمة، المؤلف: أبو بكر أحمد

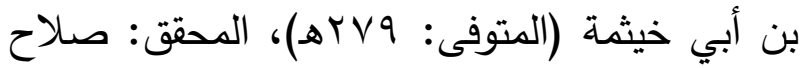
بن فتحي هلال، الناشر: الفاروق الحديثة للطباعة

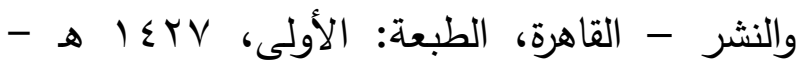

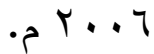
ه- تاريخ دمثق لابن عساكر، المؤلف: أبو القاسم علي بن الحسن بن هبة الله المعروف بابن عساكر

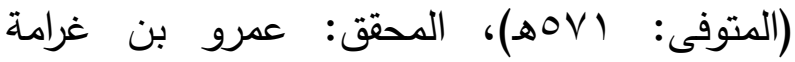
العمروي، الناشر : دار الفكر للطباعة والنشر والتوزيع، عام النشر: 10 10 هـ - 1990 م. צ- تفسير ابن كثير، المؤلف: أبو الفداء إسماعيل بن عمر بن كثير القرشي البصري ثم الدمشي

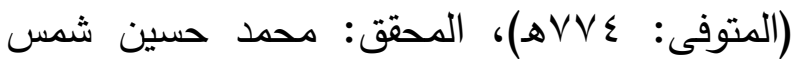
الدين، الناشر: دار الكتب العلمية، منشورات محمد علي بيضون - بيروت، الطبعة: الأولى - 9 1ـ 1 هـ

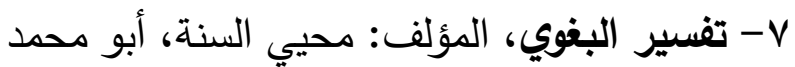
الحسين بن مسعود البغوي (المتوفى: • (0ه)، المحقق: حققه وخرج أحاديثه محمد عبد الله النمر -

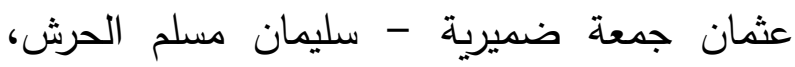
الناشر : دار طيبة للنشر والتوزيع، الطبعة: الرابعة، . 199V - ه 1 1 1 VIV 1- تفسير الثعالبي، المؤلف: أبو زيد عبد الرحمن بن محمد بن مخلوف الثعالبي (المتوفى: مهنه)،

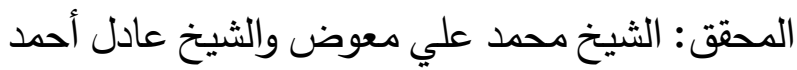
عبد الموجود، الناشر: دار إحياء التراث العربي -

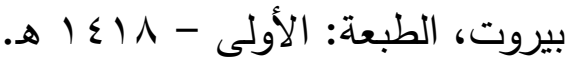


• r - شرح الزرقاني على المواهب اللدنيةّ بالمنح

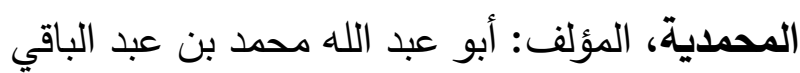
بن يوسف بن أحمد بن شهاب الدين بن محمد الزرقاني

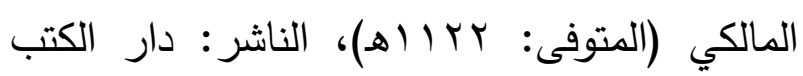

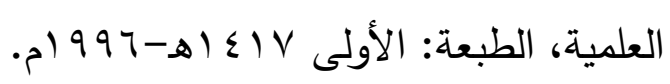
ا ا- صحيح البخاري، المؤلف: محمد بن إسماعيل

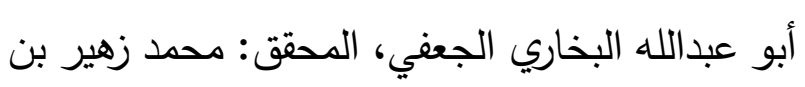
ناصر الناصر، الناشر: دار طوق النجاة، الطبعة:

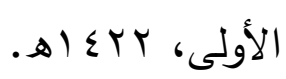
r r - صحيح مسلم، المؤلف: مسلم بن الحجاج أبو اله الحسن القشيري النيسابوري (المتوفى: ابrاهـ)، المحقق: محمد فؤاد عبد الباقي، الناشر: دار إحياء

$$
\text { التراث العربي - بيروت. }
$$

r r - طبقات الثافعيين، المؤلف: أبو الفذاء إسماعيل بن عمر بن كثير القرشي البصري ثم الدمشقي

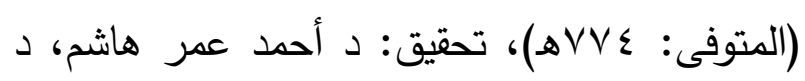
محمد زينهم محمد عزب، الناشر: مكتبة الثقافة

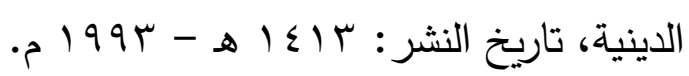
؟ ب- الطبقات الكبرى، المؤلف: أبو عبد الله محمد

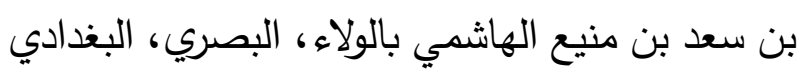

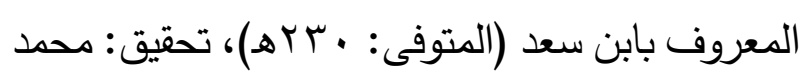
عبد القادر عطا، الناشر: دار الكتب العلمية -

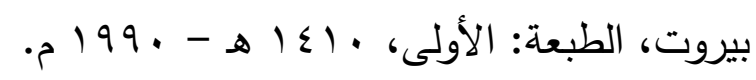

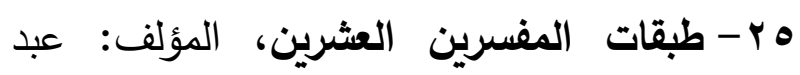
الرحمن بن أبي بكر ، جلال الدين السيوطي (المتوفى:
1 ه - الجرح والتعديل، لمؤلف: أبو محمد عبد الرحمن

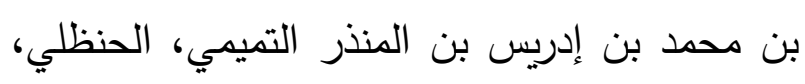

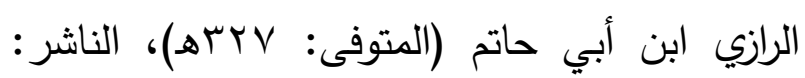

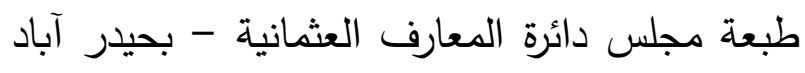

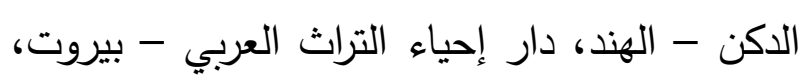

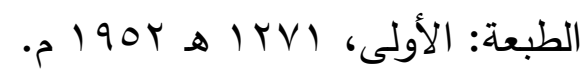

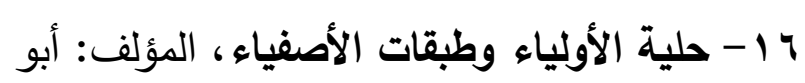

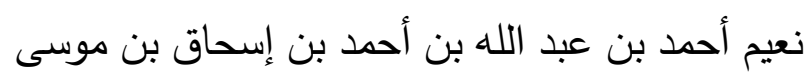
بن مهران الأصبهاني (المتوفى: · بـعه)، الناشر:

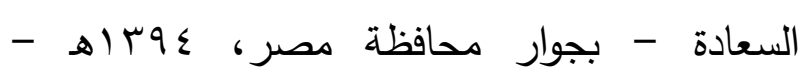
، $9 \vee \varepsilon$

IV

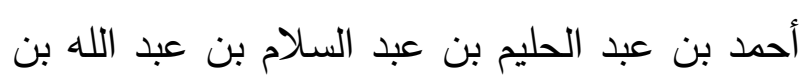
أبي القاسم بن محمد ابن تيمية الحراني الحنبلي

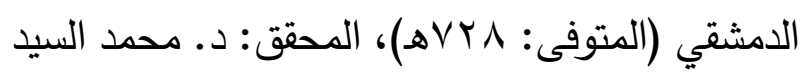

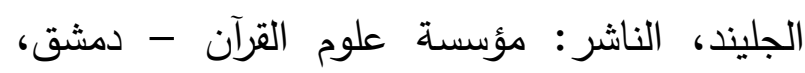
الطبعة: الثانية، عـ ــ الهـ 1 ا - ذيل طبقات الحفاظ، المؤلف: عبد الرحمن بن اهن أبي بكر ، جلال الدين السيوطي (المتوفى: (1) الهـ)،

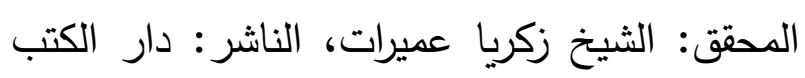
العلمية. 9 ا 19 عبد الله الحسيني الألوسي (المتوفى: • • الهـ)،

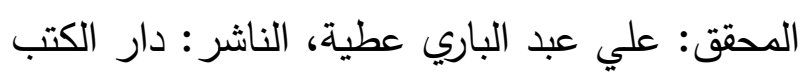

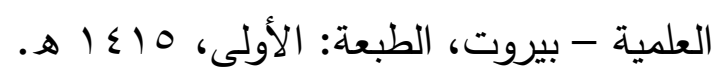


الرويفعي الإفريقي (المتوفى: الاهـ)، الناشر: دار

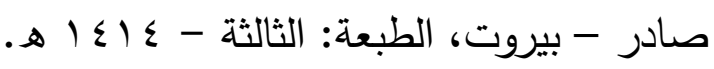

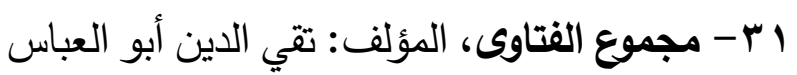
أحمد بن عبد الحليم بن تيمية الحراني (المتوفى: A

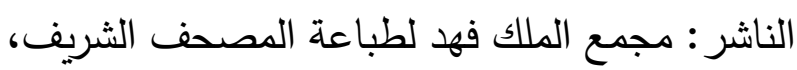
المدينة النبوية، المملكة العربية السعودية، عام النشر:

$$
\text { (990/8) }
$$

r r - المدخل إلى السنن الكبرى للبيهقي، المؤلف:

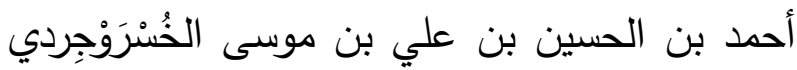

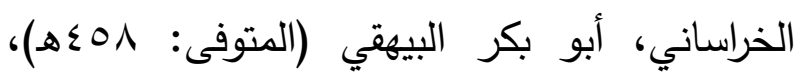

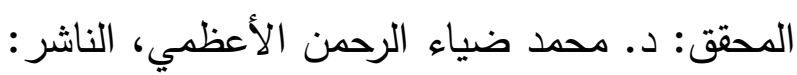
دار الخلفاء للكتاب الإسلامي - الكويت. ץ ب- المسائل والأجوبة في الحديث والتفسير، المؤلف: أبو محمد عبد الله بن مسلم بن قتيبة الدينوري

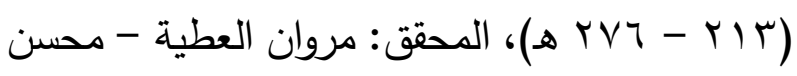

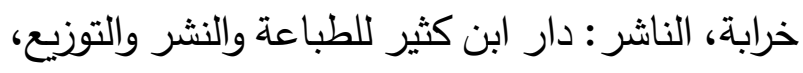

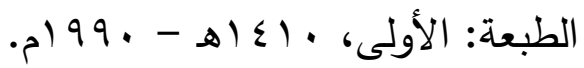
ء ب - مقدمة في أصول التفسير، المؤلف: تقدي الدين

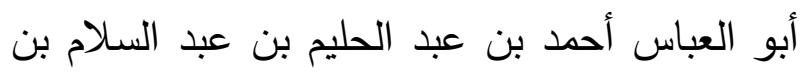

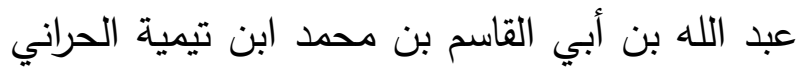

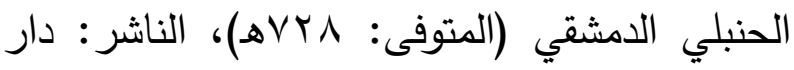

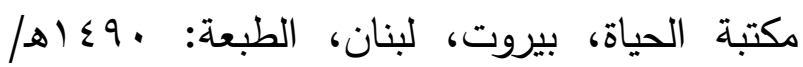

$$
\text { . } 191 \text {. }
$$

هـ - مناهج المفسرين، المؤلف: منيع بن عبد الحليم

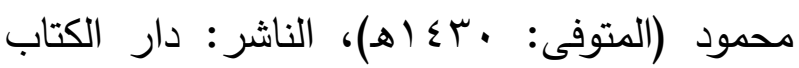

(19هـ)، المحقق: علي محمد عمر، الناشر: مكتبة

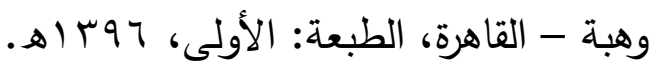
צ - الفتاوى الكبرى، المؤلف: تقي الدين أبو العباس اله

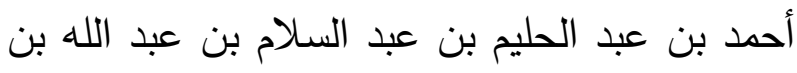
أبي القاسم بن محمد ابن تيمية الحراني الحنبلي

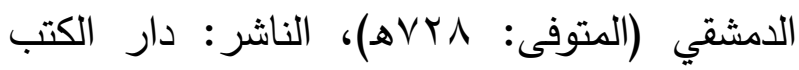

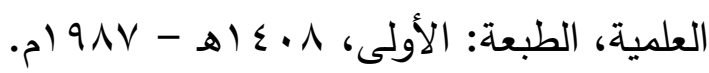

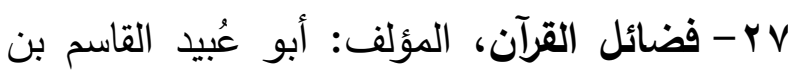
سلاّم بن عبد الله الهروي البغدادي (المتوفى: צYTه)، تحقيق: مروان العطية، ومحسن خرابة، ووفاء تقي الدين، الناشر: دار ابن كثير (دمشق مانق

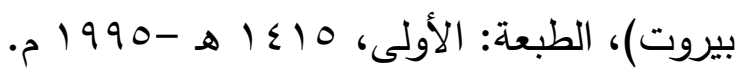

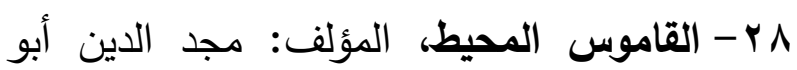
طاهر محمد بن يعقوب الفيروزآبادى (المتوفى: هـ N V V الرسالة، بإشراف: محمد نعيم العرقسُوسي، الناشر: مؤسسة الرسالة للطباعة والنشر والتوزيع، بيروت -

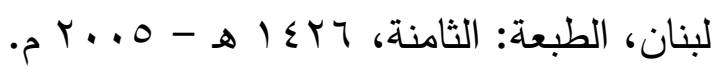
q ץ - كشف الظنون عن أسامي الكتب والفنون، المؤلف: مصطفى بن عبد الله كاتب جلبي القسطنطيني المشهور باسم حاجي خليفة أو الحاج

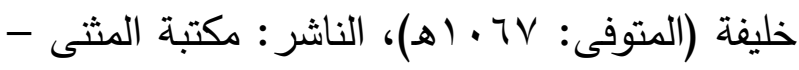

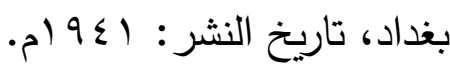

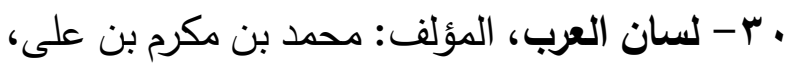
أبو الفضل، جمال الدين ابن منظور الأنصاري 


$$
\text { صالح بن أحمد بن عبيد العلوي }
$$

المصري - القاهرة، دار الكتاب اللبناني - بيروت، الطيب/ دار العلوم الإنسانية - دمشق، الطبعة:

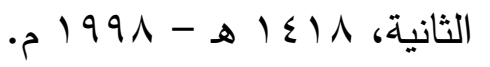

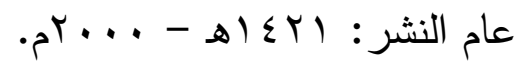

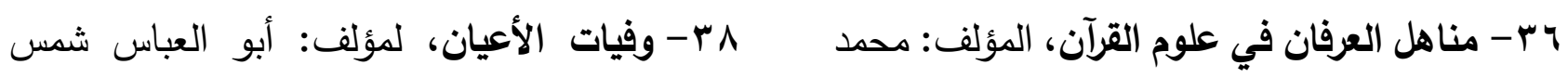

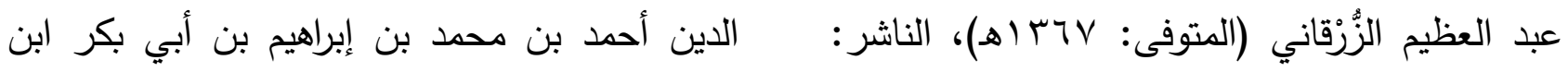

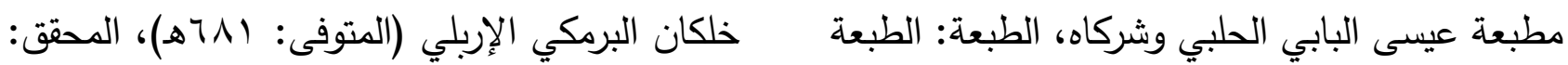
إحسان عباس، الناشر: دار صادر - بيروت. الثالثة. V V - الواضح في علوم القرآن، المؤلف: مصطفى ديب البغا، محيى الدين ديب مستو، الناشر : دار الكلم 


\title{
The Phenomenon of Modern-day Weakness in Tafsir Skills and Ways to Address it
}

\author{
Dr. Salih Ahmed Alalawi \\ Assistant Professor of Qur'an and Sunna, Department of Sharia and Islamic Studies. \\ Faculty of Arts and Humanities, King Abdulaziz University
}

\begin{abstract}
Tafsir skills and ways to address it. I have reviewed the definition of Tafsir, its emergence, schools, types, stages from the stage of emergence, to the stage of weakness. The research affirms the necessity of reviving the science of Tafsir in the modern era, and outlines the reasons for its need. The research upholds that every age must have its own exegetes who can better understand the peculiarities of that era, and accordingly produce an accessible interpretation that can address these peculiarities.

The research reviews the signs of modern-day weakness in Tafsir skills, including the scarcity of Tafsir publications, weakness in their scholarships, and the total reliance on previous works. The research then discussed thirty-five reasons for that weakness that are believed to have caused this weakness both at the levels of individuals and societies. The research concludes with a statement of forty-two means to treating this phenomenon, and the responsibility of the individual, family and society in addressing this phenomenon.
\end{abstract}

